\title{
Phylogeny and classification of early European Mustelida (Mammalia: Carnivora)
}

\author{
Mieczysław WOLSAN
}

Wolsan M. 1993. Phylogeny and classification of early European Mustelida (Mammalia: Carnivora). Acta theriol. 38: 345 - 384.

A phylogenetic analysis of the Oligocene and some Neogene European arctoid carnivorans of the order-group taxon Mustelida is performed, based on characters of the skull and dentition. The following classification of the revised genera is proposed: Simocyon (Ailurus, Amphictis, Bavarictis, Potamotherium (Pseudobassaris (Angustictis gen. n., Broiliana)) (Mustelictis ((Franconictis gen. n., Stromeriella) (Bathygale gen. n. (Plesictis (Paragale, Plesiogale)|)) )). Potamotherium is allied to phocids within the monophyletic Pinnipedia. Pseudobassaris, Angustictis gen. n., and Broiliana are considered procyonids. Mustelictis, Franconictis gen. n., Stromeriella, Bathygale gen. n., Plesictis, and the mustelines Paragale and Plesiogale are placed in the Mustelidae. Parailurus is included in Ailurus, and Ichneugale (= Viretius, $=$ Alopecocyon) is synonymized with Amphictis. Phylogenetic definitions and diagnoses are provided for the suprageneric taxa: Carnivora, Caniformia, Arctoidea, Arctomorpha (new), Mustelida, Pinnipedia, Procyonidae, Mustelidae, and Mustelinae.

Mammal Research Institute, Polish Academy of Sciences, 17-230 Biatowieza, Poland, and Institut für Geowissenschaften (Paläontologie), Johannes Gutenberg-Universität Mainz, D 55099 Mainz, Germany

Key words: phylogenetic systematics, Camivora, Caniformia, Arctoidea, Arctomorpha, Mustelida, Simocyon, Ailurus, Amphictis, Bavarictis, Pinnipedia, Potamotherium, Procyonidae, Pseudobassaris, Angustictis, Broliana, Mustelidae, Mustelictis, Franconictis, Stromeriella, Bathygale, Plesictis, Mustelinae, Paragale, Plesiogale, Oligocene, Nengene, Europe

Contents

$\begin{array}{ll}\text { Introduction } & 345 \\ \text { Material } & 347\end{array}$

Abbreviations for collections $\quad 347$

Specimens examined $\quad 347$

$\begin{array}{ll}\text { Character analysis } & 349\end{array}$

Phylogenetic reconstruction $\quad 360$

$\begin{array}{ll}\text { Classification } & 361\end{array}$

References $\quad$. 379

\section{Introduction}

Early mustelidan carnivorans are apparently best documented from the European Tertiary. Especially the Oligocene and Early Miocene formations of France 
and southern Germany, constituting a favoured field of research for many of our scientific predecessors, have yielded abundant material of primitive mustelidans. Studies of the European Mustelida have been carried out for more than 150 years, resulting in an impressive accumulation of bibliographic references. At present, however, it is often difficult to avoid misunderstanding when employing vague diagnoses of mustelidan taxa created during the epoch of the pioneers. Cladistics is now generally accepted as the philosophy and methodology of choice in phylogenetic inference and taxonomy. It is thus no longer possible to follow phylogenetic reconstructions and classifications proposed in the past as using overall similarity instead of special similarity, paraphyletic as opposed to monophyletic taxa, and taxonomic congruence rather than character congruence.

The first cladogram of the Carnivora, involving the major groups of mustelidans, was proposed by Tedford (1976). Although his hypothesis had been put forward in conflict with the premises of cladistic methodology (Wiig 1983), it was accepted at that time and played an important part, stimulating many systematists to further efforts to reconstruct the phylogeny of carnivorans, particularly pinnipeds.

Schmidt-Kittler (1981) presented a second attempt at distinguishing the major clades of mustelidan carnivorans. Through an analysis of primitive and derived features of the basicranium and dentition, he proposed a testable hypothesis of the phylogenetic relationships for non-marine mustelidans. His comparative analysis of the auditory region in many fossil and extant arctoids documented the phylogenetic significance of morphological transformations in this part of the cranium. Schmidt-Kittler's phylogeny of the Mustelida, based primarily on his pioneering interpretation of the transformation of the suprameatal fossa, represents an important step in the advancement of our understanding of the evolutionary history of this group. His study revealed a lack of knowledge of interrelationships among early mustelidans and the need for a taxonomic revision of these forms.

In the meantime, a number of alternative cladograms of the Mustelida have been proposed (Ginsburg 1982, Cirot 1988, 1992, Flynn et al. 1988, Baskin 1989, Wozencraft 1989, Wyss and Flynn 1993). However, though much has recently been written on phylogenetic relationships of mustelidan carnivorans, the critical Oligocene and Early Miocene forms have remained largely ignored.

This paper presents the results of a phylogenetic analysis of craniodental characters of the early European mustelidans and their taxonomic revision at a generic level, providing a new approach to mustelidan phylogeny and classification. To avoid terminological ambiguity, I use names "mustelidan" and "ursidan" for members of the Mustelida and the Ursida, respectively, employing "mustelid" and "ursid", as usually applied, to representatives of the families Mustelidae and Ursidae.

Chronostratigraphic units as used in this paper correspond to the following European land mammal ages and Mammal Paleogene (MP) and Neogene (MN) zones (Schmidt-Kittler et al. 1987, Mein 1990): Early Oligocene, Rupelian, MP 21-24; Late Oligocene, Chattian, MP 25-30; Early Miocene, Agenian plus Orleanian, 
MN 1-5; Middle Miocene, Astaracian, MN 6-8; Late Miocene, Vallesian plus Turolian, MN 9-13; Early Pliocene, Ruscinian, MN 14-15; Late Pliocene, Villanyian, MN 16-17. For correlations of the European and North American land mammal ages see Lindsay and Tedford (1990).

\section{Material}

\section{Abbreviations for collections}

AMNH American Museum of Natural History, New York, U.S.A.

BSP Bayerische Staatssammlung für Paläontologie und Historische Geologie, Munich, Germany

FSL Département des Sciences de la Terre, Université Claude Bernard, Lyon, France

FSM Laboratoire de Géologie, Université de Provence, Marseille, France

IGM Institut für Geowissenschaften, Johannes Gutenberg-Universität Mainz, Germany

ISE Laboratoire d'Évolution des Vertébrés, Université des Sciences et Techniques du Languedoc, Montpellier, France

ISEZ Instytut Systematyki i Ewolucji Zwierząt, Polska Akademia Nauk, Cracow, Poland

MGHN Musée Guimet d'Histoire Naturelle, Lyon, France

MGL Musée Géologique Cantonal, Lausanne, Switzerland

MHNM Musée d'Histoire Naturelle, Montauban, France

MHNT Muséum d'Histoire Naturelle, Toulouse, France

MNHN Institut de Paléontologie, Muséum National d'Histoire Naturelle, Paris, France

MNHU Museum für Naturkunde, Humboldt-Universität, Berlin, Germany

NHM Natural History Museum, London, United Kingdom

NMB Naturhistorisches Museum Basel, Switzerland

PDV Private collection of D. Vidalenc, Saint Gaudens, France

PVPH Laboratoire de Paléontologie des Vertébrés et Paléontologie Humaine, Université Pierre et Marie Curie, Paris, France

SMF Forschungsinstitut und Naturmuseum Senckenberg, Frankfurt am Main, Germany

SMN Staatliches Museum für Naturkunde, Stuttgart, Germany

UK Geologický a Paleontologický Ủstav, Universita Karlova, Prague, Czech Republic

YPM Yale Peabody Museum, Princeton University Collection, New Haven, U.S.A.

ZM Zoologisk Museum, Copenhagen, Denmark

ZSM Zoologische Staatssammlung, Munich, Germany

\section{Specimens examined}

Materials of the following genera of the Mustelida formed the focus of the study:

Simocyon Wagner, 1858 (Late Miocene and Early Pliocene, Eurasia; Early Pliocene, North America) - Skulls plus mandibles: BSP AS II 52, NHM M9032a-h. Facial-palatal portion of skull: BSP AS II 51. Mandibles: BSP AS II 53, NHM M412 [cast].

Ailurus Cuvier, 1825 (Pliocene, Europe and North America; Pliocene to Recent, Asia) - Skulls plus mandibles: NHM 75.2338; NMB 10094; SMF 12743, 39290; ZSM 1953/98. Mandible: SMF Wö301. Teeth: SMF Wö142, Wö144, Wö148, Wö219, Wö239/1-6; UK OF65371, OF65372.

Amphictis Pomel, 1853 (Late Oligocene to Middle Miocene, Europe) - Skull: ISEZ MF2130/93. Cranium: BSP 1952 11 4769. Facial-palatal portion of skull: BSP 1952 Il 21. Maxillae: BSP 1937 II 13357, 13371, 13392, 13393, 13399, 13402, 13545; FSL 97711, 212860 [cast], 213850 [cast]; MHNM Qu2; NMB GA5729 [cast]. Mandibles: BSP 1879 XV 74 lonly mandible, not ${ }^{1}$ ]; BSP 1881 LX 15a, 571; 
BSP 1937 II 13124-13132, 13134-13139, 13141-13145, 13147-13149, 13213-13215, 13221, 13222, $13227,13228,13243,13248,13250,13257,13419,13516,13607,13608,13895$, 14883; FSL 4294 lold no.], 213846, 213848, 213849; FSM PQ283; ISE UM1841-1843; MGHN StG768, StG779-782, StG783 [cast]; MHNM MTB13, Qu1; MHNT GER259; MNHN Qu9238, Qu9240, Qu9242-9246, SG12307; NHM 31057, 31058, M1651, M1656, M2381, M9632; NMB GA5729 [cast], LM554, SG15495, SG19457. Teeth: BSP 1881 IX 28 [only $\mathrm{M}^{1}$, not $\mathrm{M}^{2}$ ], 572; BSP 1937 II 13708, 13710, 13711, 13723, 13726, 14484, 14488, $14523,14529,14531,14735-14738,14866,14867,14876,14878-14882,14927,14946-14948,14950$, 14953, 14954, 14982, 14983, 14987; BSP 1947 III 4; BSP 1976 XXII 3423-3426, 3463, 3667; FSL 213048; ISEZ MF2129/93; NMB Cod5-7, LCh242, Pa1061; PDV Dp245, Dp247, Dp256, Mb43.

Bavarictis Mödden, 1991 (Late Oligocene, Europe) - Skull: BSP 1952 II 5. Facial-palatal portion of skull plus mandible: BSP 1952 II 8. Facial-palatal portions of skull: BSP 1952 II 6, 7. Maxilla: BSP 1952 II 10. Mandibles: BSP 1952 II 3336 lonly dentary with $\mathrm{P}_{2}, \mathrm{P}_{4}$, and $\mathrm{M}_{1}$; not $\mathrm{P}_{3}$, NHM M9637. Teeth: BSP 1952 II 11, 12, 4770-4772.

Potamotherium Geoffroy Saint-Hilaire, 1833 (Late Oligocene to Late Miocene, Europe) - Skulls: BSP 1885 I 13, NMB Ph3653. Cranium: NMB MA905. Auditory portions of cranium: NMB MA1203, SG7539, SG18512, SG18513, SG20935. Facial-palatal portion of skull: NMB SG14041. Maxillae: NMB SG6922, SG11021. Mandibles: BSP 1885 I 501, 1964 I 225, 1967 I 224 [cast], 1972 I 12 [cast]; NMB MA703, MA915, SG227, SG3784, SG6941, SG10750, SG12302, SG12304, SG17382, SG17900. Teeth: NMB MA2972, MA2974-2976. Endocranial cast: BSP 1971 I 147.

Pseudobassaris Pohle, 1917 (Late Oligocene, Europe) - Skull plus mandible: ZM 144. Skull: YPM 11455 [cast]. Maxillae: MHNT PHQ340; MNHN Qu8978; NHM M2361A, M2361C. Mandibles: BSP 1879 XV 713, 716, 718; MHNM Qu4-6; MNHN Qu9130, Qu9133, Qu9135; NMB QuB450, QuC66.

Angustictis gen. n. (Early Miocene, Europe) - Facial-palatal portion of skull plus mandible: BSP 1937 II 13281. Maxillae: BSP 1937 II 13556, 13576. Mandibles: BSP 1937 II 13260-13263, 13265, $13266,13268-13272,13274,13276,13278-13280,13505-13511,13513,13626-13649,13889$, 1389113893; BSP 1976 XXII 3416, 3417. Teeth: BSP 1937 II 13699-13705, 14884-14892, 14894-14903, 14905-14918, 14936, 14938; BSP 1976 XXII 3418, 3419, 3651-3653.

Broiliana Dehm, 1950 (Early Miocene, Europe) - Skulls: BSP 1937 II 13524, 13525. Crania: BSP 1937 II 13526-13532, 13537. Auditory portions of cranjum: BSP 1937 II 13602-13604. Facial-palatal portion of skull plus mandible: BSP 1937 II 13555. Facial-palatal portion of skull: BSP 1937 Il 13558. Maxillae: BSP 1937 II 13360-13367, 13548, 13550-13553, 13593-13595; BSP 1976 XXII 3475. Mandibles: BSP 1937 II 13151-13155, 13157, 13158, 13160-13166, 13169, 13172, 13173, 13176, $13178,13181,13182,13184-13187,13193,13194,13198-13200,13202,13203,13205,13207-13209$, $13343,13596,13598$. Teeth: BSP 1937 Il 13009 lonly $\mathrm{M}_{2}$, not dentary with $\mathrm{P}_{3}-\mathrm{M}_{1}$ ], 13159, 13167 , $13168,13177,13179,13180,13183,13188,13195-13197,13206,13442,13443,13580,13667-13678$, 13681-13685, 14333-14371, 14373-14392, 14493, 14495, 14499, 14500, 14516-14522, 14524-14528, $14530,14532-14549,14551-14616,14618-14642,14647,14667-14670,14672-14676,14678,14680$, 14682-14689, 14691, 14693, 14893; BSP 1976 XXI 3433-3446, 3450-3462, 3464, 3466-3468, 3476, 3477. Endocranial cast: BSP 1971 I 149.

Mustelictis Lange, 1969 (Early Oligocene, Europe) - Skulls: NHM M7490, PVPH unnumbered (holotype of Mustelictis piveteaui). Mandibles: FSM PQ294; MHNM Qu3; MHNT PHQ169, PHQ348; MNHN Qu9121; NHM M1372; NMB QuB299, QuC77, QuC378; ZM 96.

Franconictis gen. n. (Early Miocene, Europe) - Crania: BSP 1937 II 13536, 13571, 13572. Auditory portion of cranium: BSP 1937 II 13605. Maxillae: BSP 1937 II 13379-13388, 13390, 13391, 13401, 13549. Mandibles: BSP 1937 II 13140, 13210-13212, 13216-13220, 13224-13226, 13229-13242, 13244-13247, 13249, 13251-13256, 13894; BSP 1976 XXII 3420, 3421. Teeth: BSP 1937 II 13389, $13691-13695,13712-13714,14864,14865,14868-14875,14919-14926,14928-14935,14937,14939-$ 14944, 14979-14981, 14984-14986; BSP 1976 XXII 3427. Endocranial cast: BSP 1971 I 151.

Stromeriella Dehm, 1950 (Early Miocene, Europe) - Skulls: BSP 1937 II 13533, 13557. Crania: BSP 1937 II 13534, 13535, 13561. Auditory portion of cranium: BSP I937 II 19604. Facial-palatal portion of skull: BSP 1937 II 13540. Maxillae: BSP 1937 II 13344-13355, 13358, 13359, 13541-13544, 
13680, 14207, 14208; BSP 1976 XXII 3514 . Mandibles: BSP 1937 II 13009 [only dentary with $\mathbf{P}_{3} \cdots \mathbf{M}_{1}$, not $\mathrm{M}_{2}$ ], 10356, 13001-13008, 13010, 13011, 13013-13017, 13019-13035, 13037-13069, 13071-13074, $13133,13156,13609,13612,13613,13616,13621,14237$; FSM 750, 787, 788, LgM13, LgM14, LgM14a. Teeth: BSP 1937 II 13305, 13679, 13686-13688, 14108-14138, 14175-14193, 14195-14206, 14225-14236, 14238-14297, 14701, 14877; BSP 1976 XXII 3479-3484, 3486-3496, 3507-3513. Endocranial cast: BSP 1971 I 150.

Bathygale gen. n. (Early Miocene, Europe) - Skulls: MNHN SG3215-3218, NHM 31022. Crania: MNHN SG3195, MNHU MBMa29336. Mandibles: FSL 97710, 213854; MGHN StG772; MHNT GER260; MNHN SG3220, SG3222, SG3223, SG3227, SG3229, SG3233, SG3240-3242, SG3245; NHM M7646; NMB MA802, SG10732.

Plesictis Pomel, 1846 (Late Oligocene to Early Miocene, Europe) - Skulls plus mandibles: AMNH 11001, NMB Chr2573. Skulls: FSL 97448, MGL 42043, MNHN LIM343, NMB Chr1168. Crania: NMB Bst3853, Cod2181. Maxillae: NMB Pa1044, Pa1045. Mandibles: FSL 7224 [old no.], 97708, 97709; FSM LgM15, LgM16; MNHN JC9, Qu9124, SG3240, SG12306; NMB Bst199, Pa1057-1060, QuB325, Sau1774, SG15496; PDV Dp244; PVPH Ph302, Ph304, Ph306-309, Ph311; ZM 93. Teeth: FSL CBr6067a-c; NMB Pa1046-1049, Pa1056, Pa1062-1065, Pa1068, Pa11878, Pa11884, Pa12120; PVPH Ph303.

Paragale Petter, 1967 (Early Miocene, Europe) - Skulls: NMB MA4641, Ph3638. Facial-palatal portion of skull: MNHN 3214a. Mandibles: MGHN StG769, StG825; MNHN 3214b; NMB MA2824, SG2098.

Plesiogale Pomel, 1847 (Early Miocene, Europe) - Skull: NMB SG2894. Mandibles: MNHN SG3191-3194, SG3203-3206; NMB MA4698, SG2895, SG2896, SG8094.

For purposes of the determination of character polarity, skulls and teeth of other fossil and Recent carnivorans housed in BSP, FSL, FSM, IGM, ISEZ, MGHN, MHNM, MNHN, MNHU, NHM, NMB, SMF, SMN, and ZSM were studied.

\section{Character analysis}

Although 66 characters of the skull and dentition were originally sampled among the early mustelidans of Europe, the alternative states could be objectively defined for only 28 of them (Figs $1-6$ ). The distribution of these character states across the genera analyzed is shown in Table 1.

The character polarity is established based on outgroup comparison (Watrous and Wheeler 1981, Farris 1982, Maddison et al. 1984), the paleontological method (Eldredge and Cracraft 1980), and the ontogenetic method (de Queiroz 1985). Bryant (1991) has recently shown that they are appropriate and equally valid procedures for determining polarity of character transformations in phylogenetic analyses.

There is general agreement on the bipartite division of the Carnivora into feliforms and caniforms, and the latter grouping into canoids (or cynoids) and arctoids. There is further agreement that arctoids related to ursids constitute the sister group to those related to mustelids (Tedford 1976, Flynn et al. 1988, Wyss and Flynn 1993). Accordingly, the following series of outgroups was used for polarity determination: (1) Ursida, defined as the most recent common ancestral species of ursids and Ailuropoda and all of its descendants, plus all arctomorphs that share an ancestral species with this clade, being not also common to the Mus telida; (2) Amphicyonidae, defined as the most recent common ancestral species 
Table 1. Distribution of the states of 28 craniodental characters in 15 genera of early European mustelidans. The character states are defined in Figs 1-6; " $\mathrm{a}$ " designates the primitive state for each character; " $\mathrm{b}$ ", "c", "d", and "e" indicate derived states. In instances in which two different states of the same character could be scored for a genus, both the states are listed in the matrix according to the assumed sequence in which they appeared in the genus. Missing data are denoted by "?" (non-preservation) or " ${ }^{n}$ (non-applicable character).

\begin{tabular}{|c|c|c|c|c|c|c|c|c|c|c|c|c|c|c|c|c|c|c|c|c|c|c|c|c|c|c|c|c|}
\hline \multirow{2}{*}{ Taxa } & \multicolumn{28}{|c|}{ Characters } \\
\hline & 1 & 2 & 3 & 4 & 5 & 6 & 7 & 8 & 9 & 10 & 11 & 12 & 13 & 14 & 15 & 16 & 17 & 18 & 19 & 20 & 21 & 22 & 23 & 24 & 25 & 26 & 27 & 28 \\
\hline Simocyon & a & a & $\mathrm{b}$ & a & $?$ & $\mathbf{a}$ & $\mathbf{a}$ & e & a & a & $?$ & be & a & $\mathbf{a}$ & a & $\mathbf{a}$ & a & $\mathrm{b}$ & $\mathbf{a}$ & $\mathrm{a}$ & $\mathrm{b}$ & $\mathbf{a}$ & $\mathrm{c}$ & $a$ & a & $\mathbf{a}$ & a & $\mathbf{a}$ \\
\hline Ailurus & a & a & b & a & $a b$ & a & $\mathbf{a}$ & c & a & b & $\mathbf{a}$ & c & a & b & $\mathrm{b}$ & $\mathbf{a}$ & $\mathbf{a}$ & b & $\mathbf{a}$ & b & $b c$ & $\mathbf{a}$ & a & d & a & a & a & b \\
\hline Amphictis & a & a & b & a & a & a & a & $a b$ & a & b & $?$ & $a b$ & a & a & a & a & a & b & $\mathbf{a}$ & $\mathrm{ac}$ & b & $\mathbf{a}$ & a & a & a & a & a & a \\
\hline Bavarictis & a & a & $\mathbf{a}$ & $\mathbf{a}$ & a & $\mathbf{a}$ & $\mathbf{a}$ & b & $\mathbf{a}$ & b & $\mathbf{a}$ & b & a & b & a & $b$ & a & b & $\mathbf{a}$ & ac & b & $\mathbf{a}$ & a & b & a & $\mathbf{a}$ & b & a \\
\hline Potamotherium & b & a & $\mathrm{b}$ & b & a & b & $\mathrm{b}$ & $\mathrm{c}$ & $\mathrm{b}$ & b & a & b & a & a & a & $\mathrm{b}$ & d & $\mathrm{ab}$ & b & $\mathrm{d}$ & b & $a b$ & $a b$ & b & b & a & $\mathrm{b}$ & a \\
\hline Pseudobassaris & a & a & $\mathbf{a}$ & $\mathbf{a}$ & b & a & $\mathrm{b}$ & $\mathbf{a}$ & c & b & $a$ & b & a & b & a & a & a & $\mathbf{a}$ & a & ac & b & $\mathbf{a}$ & a & $\mathrm{b}$ & a & a & $a b$ & a \\
\hline Angustictis gen. $\mathrm{n}$. & $?$ & $?$ & $\mathbf{a}$ & $?$ & $?$ & $?$ & $?$ & $?$ & $?$ & $?$ & $?$ & b & a & b & a & $\mathbf{a}$ & a & b & $\mathbf{a}$ & c & $a b$ & a & a & $\mathbf{c}$ & a & $\mathbf{a}$ & a & a \\
\hline Broiliana & a & a & $\mathbf{a}$ & b & b & a & b & a & c & b & a & $\mathbf{a}$ & a & $a b$ & a & $\mathbf{a}$ & a & b & $\mathbf{a}$ & a & $a b$ & $\mathbf{a}$ & a & $\mathbf{c}$ & a & a & a & a \\
\hline Mustelictis & $\mathrm{a}$ & a & $\mathbf{a}$ & $\mathbf{a}$ & a & a & a & a & d & b & a & b & a & $\mathbf{b}$ & a & $\mathbf{a}$ & a & $a b$ & a & ac & $\mathrm{b}$ & $a$ & a & $a b$ & $\mathbf{a}$ & $\mathbf{a}$ & $\mathrm{b}$ & $a$ \\
\hline Franconictis gen. $\mathrm{n}$. & ? & a & $?$ & b & b & a & b & b & d & b & b & $?$ & a & b & a & $\mathbf{a}$ & a & b & $\mathbf{a}$ & c & b & $\mathbf{a}$ & a & a & a & $\mathbf{a}$ & b & $\mathbf{a}$ \\
\hline Stromeriella & a & a & a & b & b & a & c & b & $d$ & b & $\mathrm{b}$ & $b$ & a & $\mathrm{a}$ & a & a & $\mathrm{a}$ & b & $\mathbf{a}$ & a & b & a & a & a & $\mathbf{a}$ & $\mathbf{a}$ & $\mathbf{a}$ & a \\
\hline Bathygale gen. n. & a & $b$ & $\mathrm{~b}$ & b & b & a & $\mathrm{bc}$ & b & $d$ & $b$ & $\mathbf{a}$ & b & a & b & a & a & a & $\mathrm{b}$ & $\mathbf{a}$ & e & $\mathrm{b}$ & $a b$ & b & b & $a b$ & $\mathbf{a}$ & $\mathrm{b}$ & $\mathbf{a}$ \\
\hline Plesictis & $\mathbf{a}$ & b & $b$ & b & ba & a & $\mathrm{b}$ & b & d & $b$ & $a$ & $b$ & a & b & a & a & b & $\mathrm{b}$ & a & $\mathrm{de}$ & $\mathrm{b}$ & $a b$ & $\mathbf{b}$ & $\mathrm{b}$ & $a b$ & $\mathbf{a}$ & $\mathrm{b}$ & a \\
\hline Paragale & $\mathbf{a}$ & a & $\mathrm{b}$ & b & b & a & c & c & e & b & $?$ & $b$ & b & b & a & b & c & b & - & $\mathrm{e}$ & $\mathrm{bc}$ & $b$ & $\mathbf{c}$ & $\mathrm{b}$ & $\mathrm{b}$ & $\mathbf{a}$ & $\mathrm{b}$ & a \\
\hline Plesiogale & $\mathbf{a}$ & a & $\mathrm{b}$ & b & b & $?$ & $?$ & b & e & $b$ & $b$ & bc & b & b & a & b & $\mathbf{c}$ & $b$ & - & e & $\mathrm{c}$ & $\mathrm{b}$ & $\mathrm{d}$ & $\mathrm{b}$ & $\mathrm{b}$ & $\mathrm{b}$ & $b$ & $\mathrm{a}$ \\
\hline
\end{tabular}


of amphicyonines and daphoenines and all of its descendants; (3) Canoidea, defined as the most recent common ancestral species of canids and all of its descendants, plus all caniforms that share an ancestral species with this clade, being not also common to the Arctoidea; (4) Feliformia, defined as the most recent common ancestral species of felids, viverrids, Nandinia, hyaenids, and herpestids, and all of its descendants, plus all carnivorans that share an ancestral species with this clade, being not also common to the Caniformia.

The justification for the polarity assigned is provided below. The characters are arranged according to anatomical region.

1. Form of postorbital region (Fig. 1) - Character state $1 \mathrm{~b}$ characterizes most adult pinnipeds and some adult lutrines. Other carnivorans exhibit condition 1a. Hence state 1a is considered plesiomorphic for the Mustelida; $1 \mathrm{~b}$ is derived.

2. Pattern of dorsal cranial crests (Fig. 1) - Configuration $2 \mathrm{~b}$ is of rare occurrence among adult carnivorans. It applies to Bathygale gen. n., Plesictis, leptarctine
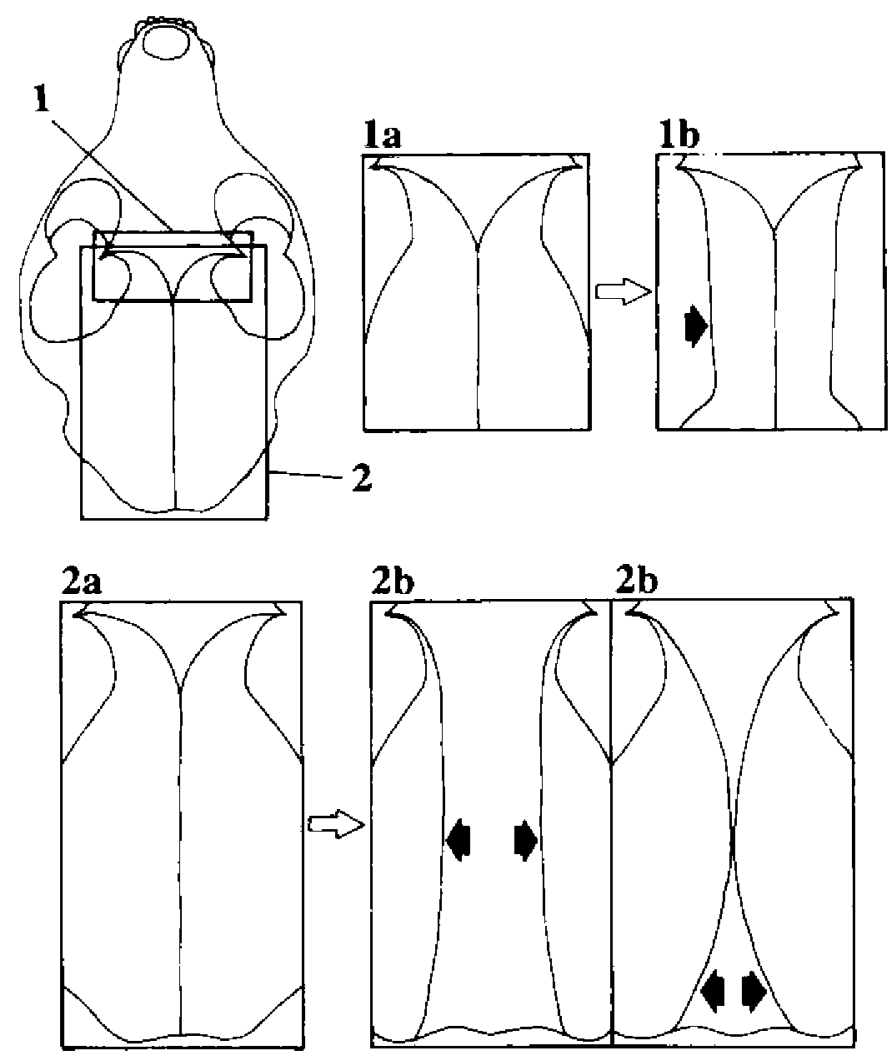

Fig. 1. Definitions of the states of characters 1 and 2 and the assigned polarity of their transformations in the early European mustelidans: 1a - pastorbital region not elongated in adults, shorter than its greatest width, $1 \mathrm{~b}$ - postorbital region greatly elongated in adults, longer than its greatest width; $2 \mathrm{a}$ - dorsal cranial crests Y-shaped in adults, sagittal crest present, $2 b$ - dorsal cranial crests parallel to $\mathrm{X}$-shaped in adults, strong parasagittal crests present. 

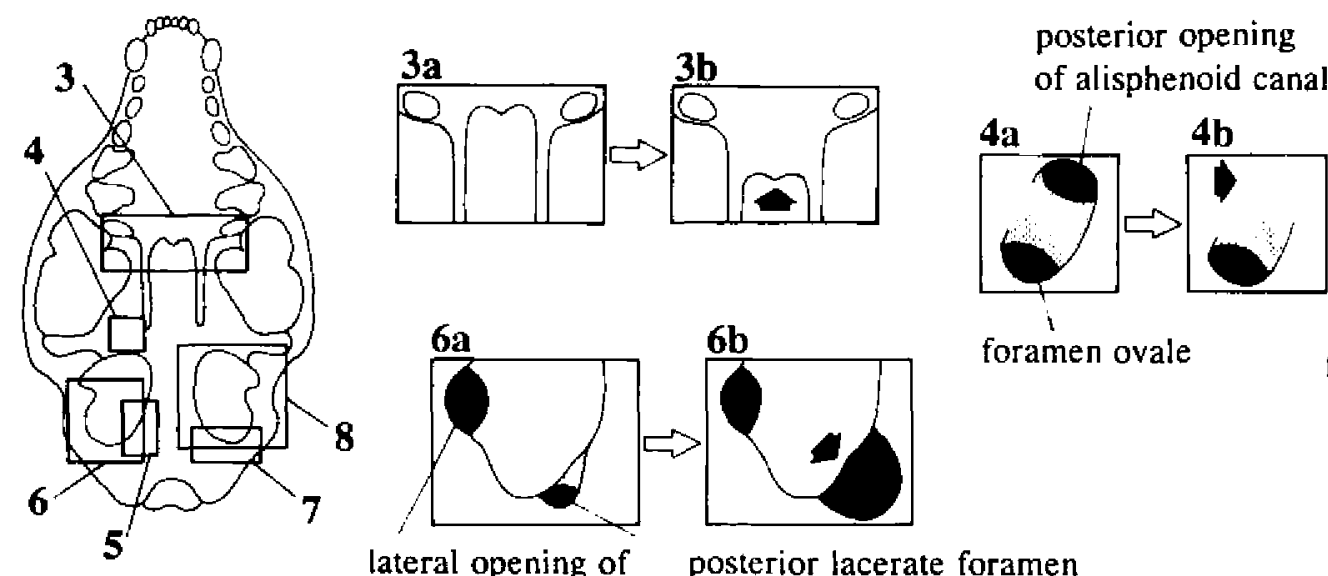

foramen ovale

fossa

lateral opening of external meatus

bulla

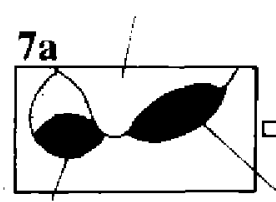

posterior

lacerate foramen

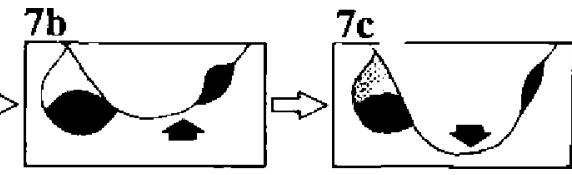

stylomastoid foramen

posterior lacerate foramen

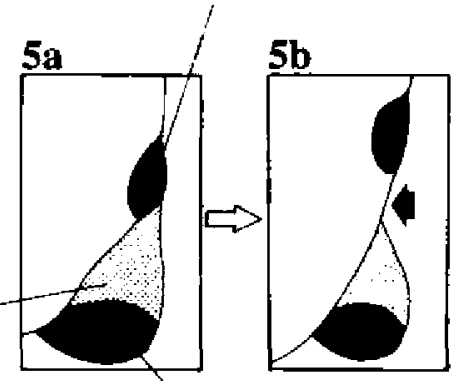

posterior lacerate foramen

Fig 2. Definitions of the states of characters 3-8 and the assigned polarity of their transformations in the early European mustelidans:3a-posterior border phenoid canal present, $4 \mathrm{~b}$-alisphenoid canal absent; $5 \mathrm{a}$ - posterior carotid foramen joined to fossa leading to posterior lacerate foramen, $5 \mathrm{~b}-$ posterior carotid foramen separated from fossa leading to posterior lacerate foramen: $6 \mathrm{a}$ - posterior lacerate foramen not enlarged, smaller than lateral opening of external auditory meatus, $6 \mathrm{~b}$ - posterior lacerate foramen greatly enlarged, greater than lateral opening of external auditory meatus; $7 \mathrm{a}-\mathrm{smallest}$ wid th of auditory bulla between stylomastoid foramen and fossa leading to posterior lacerate foramen smaller than greatest diameter of stylomastoid foramen, $7 \mathrm{~b}-\mathrm{smallest}$ width of auditory bulla beteen st diameter of stylomastoid foramen, posterior border of caudal entotympanic situated in front of that of fossa leading to posterior lacerate foramen, $7 \mathrm{c}-$ smallest width of auditory bulla between stylomastoid foramen and fossa leading to posterior lacerate foramen to posterior lacerate foramen, $7 \mathrm{c}-$ stylomastoid foramen, posterior border of caudal entotympanic situated behind that of fossa leading to posterior lacerate foramen; $8 \mathrm{a}-\mathrm{meatal}$ trough of ossified ectotympanic not differentiated, $8 \mathrm{~b}$ - meatal trough of ossified ectotympanic short, its smallest mediolateral dimension smaller than one-third of bullar width, $8 \mathrm{c}$ - meatal trough of ossified ectotympanic long, its smallest mediolateral dimension greater than one-third of bultar width. 
mustelids (Qiu and Schmidt-Kittler 1982), and Melogale (= Helictis), being a variable feature in Pliotaxidea (Wagner 1976) and Taxidea (Heráñ 1974: fig. 3). Therefore state $2 \mathrm{a}$ is retained in the Mustelida ancestrally; condition $2 \mathrm{~b}$ represents the derived configuration. State $2 a$ is hypothesized to be secondarily derived in the Mustelinae.

3. Posterior extension of palate (Fig. 2) - Character state 3a is assumed to be ancestral for the Mustelida because it is characteristic of most canoids and Paleogene ursidans (Amphicynodon, Cirot 1992: pl. VL/fig. 3; Parictis, Clark et al. 1967: fig. 10/2; Cephalogale, de Beaumont 1965: fig. 14a), some early pinnipeds (Kolponomos, Stirton 1960: fig. 3), the earliest known procyonids (Pseudobassaris, Angustictis gen. n., Broiliana), and primitive mustelids (Mustelictis, Bassariscus, Stromeriella). Consequently, condition $3 \mathrm{~b}$ is regarded as the derivative state.

4. Occurrence of alisphenoid canal (Fig. 2) - All canoids, amphicyonids, and ursidans except Ailuropoda display character state 4a. Thus state 4a occurs in the Mustelida ancestrally; $4 \mathrm{~b}$ is derived.

5. Position of posterior carotid foramen (Fig. 2) - Outgroup comparisons with the Ursida and Amphicyonidae provide evidence that configuration 5a is primitive within the Mustelida, whereas condition $5 \mathrm{~b}$ is derived. The appearance of configuration 5a in Early Miocene representatives of Plesictis (NMB Chr1168 and Chr2573) is clearly a secondary development, as evidenced by the presence of state $5 b$ in the Late Oligocene members of this genus.

6. Size of posterior lacerate foramen (Fig. 2) - Among carnivorans, condition $6 \mathrm{~b}$ is restricted in occurrence to pinnipeds and many lutrines. Hence state $6 \mathrm{a}$ is interpreted as primitive for the Mustelida, and $6 \mathrm{~b}$ as derived.

7. Posterior extension of caudal entotympanic (Fig. 2) - Both outgroup comparisons with the ursidans and amphicyonids and evidence from the ontogeny of many extant mustelidans (Hunt 1974) demonstrate that a caudal entotympanic that is unexpanded posteriorad is primitive, whereas an expanded one is derived. Accordingly, configuration $7 \mathrm{a}$ is considered the ancestral condition for the Mustelida; $7 \mathrm{~b}$ and $7 \mathrm{c}$ are derivative states, with $7 \mathrm{~b}$ being unquestionably intermediate between $7 \mathrm{a}$ and $7 \mathrm{c}$.

8. Lateral extension of ectotympanic (Fig. 2) - The ontogeny of the auditory bulla as observed in living carnivorans provides evidence that little or no lateral prolongation of the ossified ectotympanic component of the external auditory tube is primitive, and that a long tubular bony meatus is derived (Hunt 1974). Character state $8 \mathrm{a}$ is therefore ancestral for the mustelidans; conditions $8 \mathrm{~b}$ and $8 \mathrm{c}$, representing successive stages of the lateral expansion of ectotympanic, constitute apomorphic arrangements. State $8 \mathrm{~b}$ plainly represents the intermediate configuration between conditions $8 \mathrm{a}$ and $8 \mathrm{c}$.

9. Configuration of suprameatal fossa (Fig. 3) - In all arctomorphs excepting post-Paleogene pinnipeds and advanced mephitines, the laterodorsal wall of the middle ear cavity is hollowed in the area adjoining the suture between squamosal and mastoid bones. This hollow was named the suprameatal fossa by Segall (1943: 

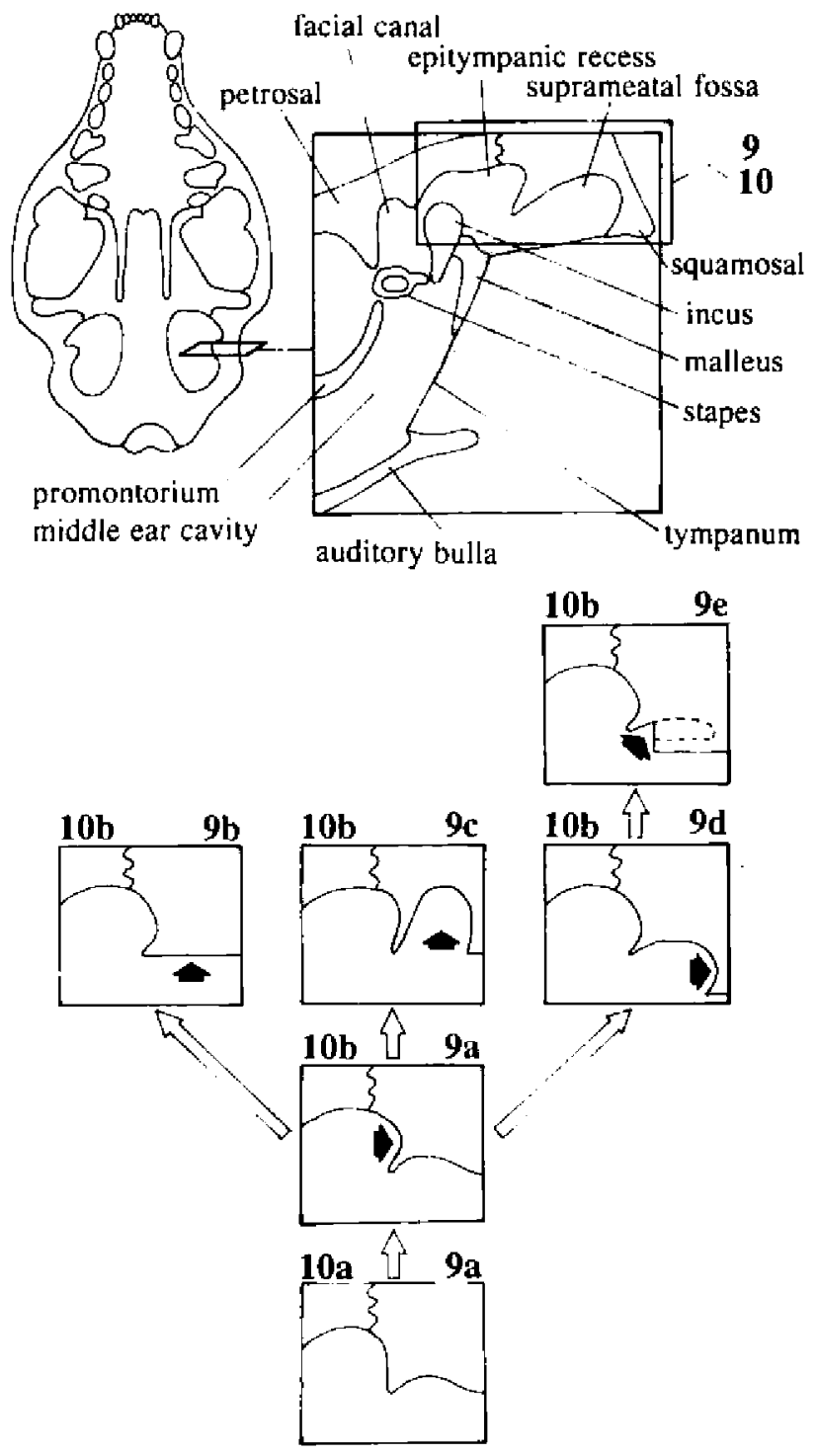

Fig. 3. Definitions of the states of characters 9 and 10 and the assigned polarity of their transforma. tions in the early European mustelidans: 9a - anterior and lateral walls of suprameatal fossa neither excavated into squamosal nor perpendicular to meatal roof, $9 \mathrm{~b}$ - suprameatal fossa absent, $9 \mathrm{c}$ - at least anterior or lateral wall of suprameatal fossa excavated into squamosal or perpendicular to meatal roof, ventral extension of medial wall of suprameatal fossa subequal to that of lateral wall, $9 \mathrm{~d}$ - at least anterior or lateral wall of suprameatal fossa excavated into squamosal or perpendicular to meatal roof, medial wall of suprameatal fossa absent or its ventral extension considerably smaller than that of lateral wall, suprameatal fossa not closed anteriorly by posterior wall of meatal tube, $9 e$ - lateral part of suprameatal fossa partially closed by posterior wall of meatal tube anteriorly; 10a - epitympanic recess anterior to fossa for incudal processus brevis not floored by squamosal, 10b - lateral part of epitympanic recess anterior to fossa for incudal processus brevis floored by squamosal. 
39). The presence of the suprameatal fossa is diagnostic of the Arctomorpha. Outgroup comparison with the Ursida provides evidence that character state 9a is retained by the mustelidans ancestrally. Condition $9 \mathrm{~b}$, shared by the post-Paleogene pinnipeds, is hypothesized to have originated by fusion of the developing external auditory tube to the roof of the 9a suprameatal fossa. The procyonid configuration (9c) evidently evolved as a result of a deep dorsal expansion of the roof of an initially shallow 9a suprameatal fossa. The early mustelid arrangement (9d) developed in consequence of great ventral extension of the lateral wall of the 9a suprameatal fossa. This statement is clearly supported by the transitional pattern of the suprameatal fossa as seen in Mustelictis. State 9e, exemplified by Leptarctus (Qiu and Schmidt-Kittler 1982: fig. 3) and early mustelines (Paragale and Plesiogale, Schmidt-Kittler 1981: figs 10,11), constitutes the intermediary stage in evolution of the mustelid suprameatal fossa, in which the fossa is initially not floored (Mustelictis) or only partially floored laterally by the developing auditory tube (Bassariscus, Schmidt-Kittler 1981: fig. 7; Franconictis gen. n., Stromeriella, Bathygale gen. $\mathrm{n}$., Plesictis) to be finally closed both ventrally and anteriorly by the posterior wall of this tube (Melogale and most mustelines, Schmidt-Kittler 1981: figs $12-15$ ). Concluding, character state $9 \mathrm{a}$ is primitive; $9 \mathrm{~b}, 9 \mathrm{c}$, and $9 \mathrm{~d}$ are independently derived from $9 \mathrm{a} ; 9 \mathrm{e}$ is derived from $9 \mathrm{~d}$.

10. Lateral extension of epitympanic recess (Fig. 3) - Numerous examples from both ontogeny and phylogeny of extant and fossil carnivorans document that a middle ear cavity of small volume, unexpanded into the surrounding basicranium, is primitive, and that increase in relative volume of the middle ear cavity, either by bulla inflation and/or expansion into surrounding basicranial bones, is derived (Hunt 1974, 1987). Accordingly, condition 10a is assumed to be ancestral for the Mustelida, whereas state $10 \mathrm{~b}$ is regarded as derived.

11. Occurrence of postlateral sulcus of brain (Fig. 4) - Examples from both phylogeny and ontogeny of carnivorans demonstrate that an unexpanded neocortex exposing a simple fissure pattern is primitive, and that the neocortical expansion in temporal and occipital areas accompanied by development of additional sulci is derived (Radinsky 1977). Therefore state 11a is retained in the Mustelida ancestrally; condition $11 \mathrm{~b}$ is an evolutionary novelty.

12. Occurrence and form of $\mathrm{P}^{1}$ (Fig. 4) - The general trend observed in dental evolution within the Carnivora is enlargement of the carnassials and simultaneous reduction of the remaining cheek teeth, including loss of the peripheral ones. Some of the lineages show a secondary hypertrophy of postcarnassial molars (e.g., post-Paleogene ursidans); however, no carnivoran is known to document an increased development of the anteriormost premolars. Accordingly, character state $12 \mathrm{a}$ is considered primitive; $12 \mathrm{~b}$ and $12 \mathrm{c}$ are regarded as derivative conditions. State $12 \mathrm{~b}$ is unquestionably intermediate between $12 \mathrm{a}$ and $12 \mathrm{c}$.

13. Occurrence of $\mathrm{P}^{4}$ carnassial notch (Fig. 4) - Character state 13a is characteristic of all carnivorans except for most mustelids that display condition $13 \mathrm{~b}$. 


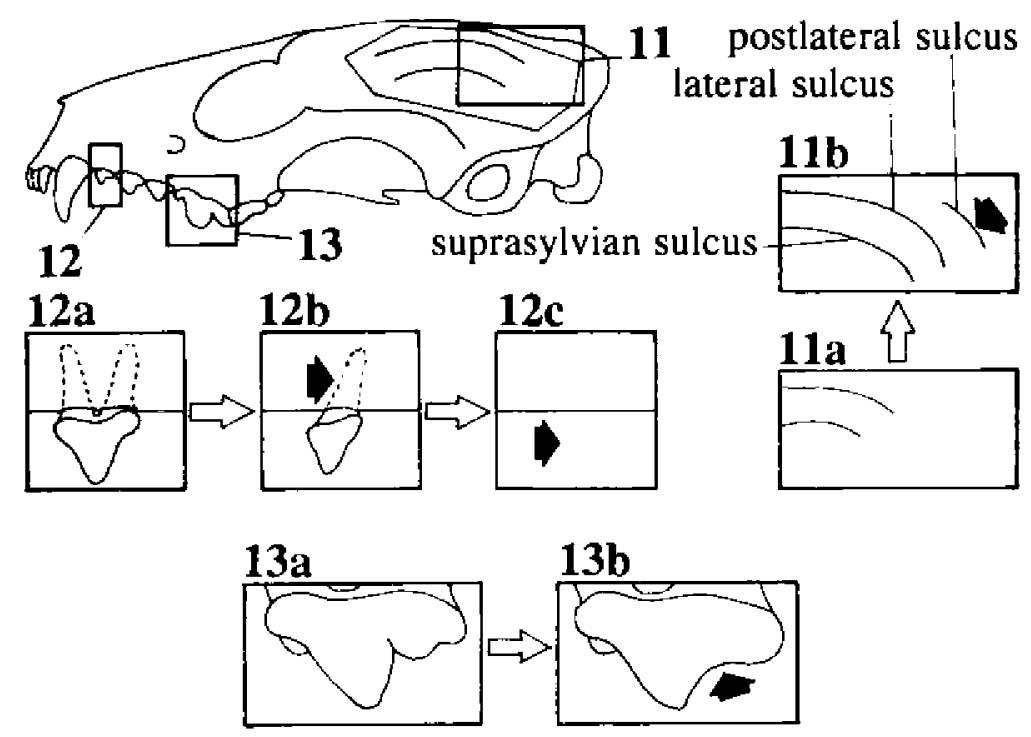

Fig. 4. Definitions of the states of characters 11-13 and the assigned polarity of their transformations in the early European mustelidans: 11a - postlateral sulcus of brain absent, $11 \mathrm{~b}$ - postlateral sulcus of brain present; $12 \mathrm{a}-\mathrm{P}^{1}$ two-rooted, $12 \mathrm{~b}-\mathrm{P}^{1}$ single-rooted, $12 c-\mathrm{P}^{1}$ absent; $13 \mathrm{a}-\mathrm{P}^{4}$ carnassial notch present, $13 \mathrm{~b}-\mathrm{P}^{4}$ carnassial notch absent.

Thus state 13a is present in the Mustelida ancestrally; 13b is an evolutionary innovation.

14. Occurrence and form of $\mathrm{P}^{4}$ protocone (Fig. 5) - Outgroup comparisons with the ursidans and amphicyonids demonstrate that condition 14 a is retained by the mustelidans ancestrally, and also confirms the derivative nature of state 14b.

15. Occurrence and form of $\mathrm{P}^{4}$ hypocone (Fig. 5) - Among mustelidans, Ailurus is unique in having configuration $15 \mathrm{~b}$. Procyon approaches this condition, but its $\mathrm{P}^{4}$ hypocone is always smaller than the protocone. In Ailuropoda the hypocone on $\mathrm{P}^{4}$ is even larger than the protocone, but the Paleogene ursidans (Amphicynodon, Cirot and de Bonis 1992; Parictis, Clark and Guensburg 1972; Nothocyon, Wang and Tedford 1992; Cephalogale, de Beaumont 1965), amphicyonids, and canoids, like most mustelidans, possess character state 15a. Thus state 15a occurs in the mustelidans ancestrally; $15 \mathrm{~b}$ represents the apomorphous arrangement.

16. Size relation of $\mathrm{M}^{1}$ to $\mathrm{P}^{4}$ (Fig. 5) - Condition 16 a is typical of canoids, amphicyonids, ursidans, and many early mustelidans (Table 1), which documents the primitive nature of this configuration and indicates that its alternative (16b) is an evolutionary novelty among mustelidans.

17. Pattern of $\mathrm{M}^{1}$ (Fig. 5) - Many canoids, amphicyonids (Springhorn 1977), and Paleogene ursidans (Amphicynodon, Cirot and de Bonis 1992; Parictis, Clark and Guensburg 1972; Cephalogale, de Beaumont 1965), as well as the Oligocene mustelidans except Plesictis exhibit condition 17a. Within the Mustelida, Plesictis 

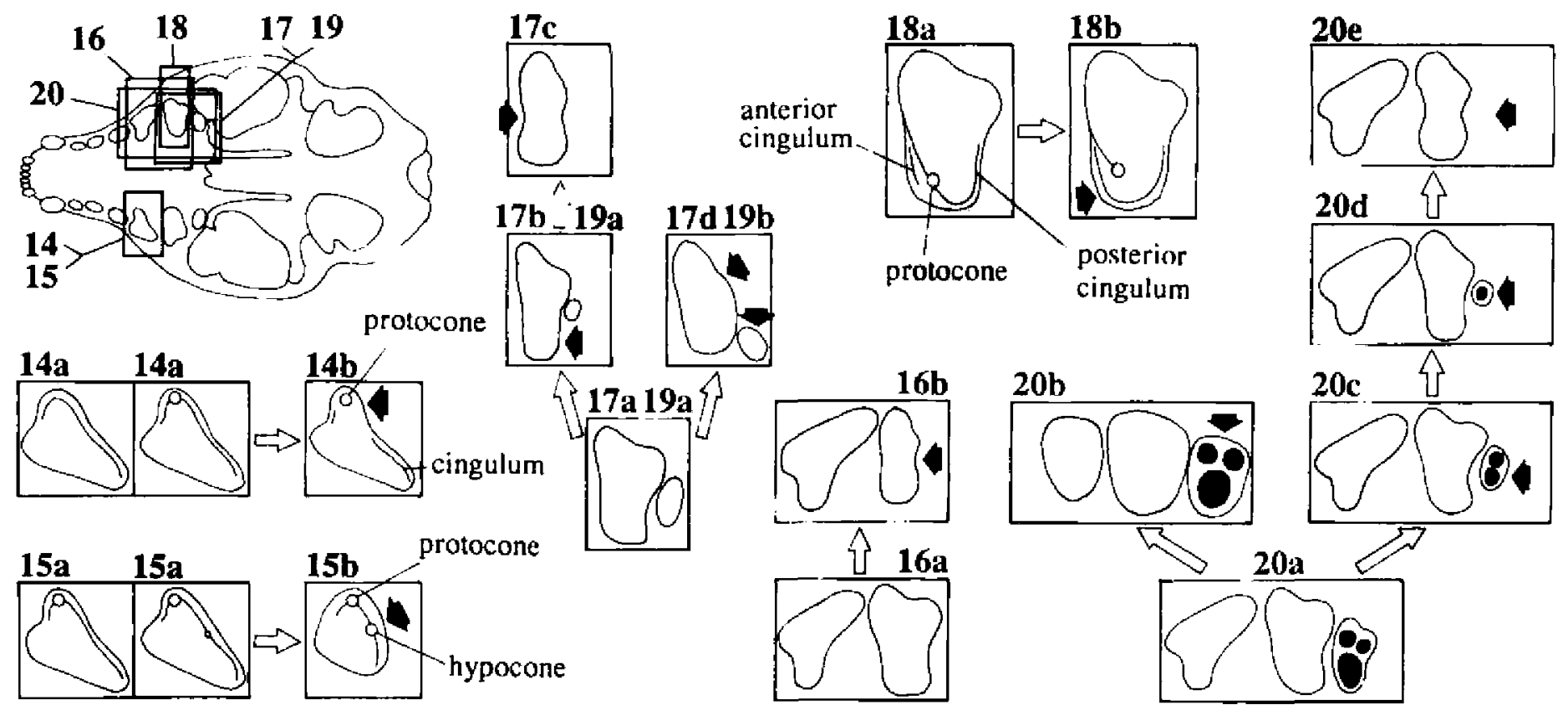

Fig. 5. Definitions of the states of characters 14-20 and the assigned polarity of their transformations in the early European mustelidans: $14 \mathrm{a}-\mathrm{P}^{4}$ protocone not differentiated or crescentic, formed by cingulum entirely, $14 \mathrm{~b}-\mathrm{P}^{4}$ protocone conical, not formed by cingulum entirely; $15 \mathrm{a}-\mathrm{P}^{4}$ hypocone notably smaller than protocone or not differentiated, $15 \mathrm{~b}-\mathrm{P}^{4}$ hypocone and protocone prominent and subequal in size; $16 \mathrm{a}-\mathrm{M}^{1}$ larger than or equal in size to $\mathrm{P}^{4}, 16 \mathrm{~b}-\mathrm{M}^{1}$ smaller than $\mathrm{P}^{4} ; 17 \mathrm{a}$ - lingual half of $\mathrm{M}^{1}$ crown shorter than buccal half, anterior and posterior borders of lingual half not parallel to each other, $17 \mathrm{~b}$ - lingual half of $\mathrm{M}^{1}$ crown shorter than buccal half, anterior and posterior borders of lingual half parallel to each other, $17 \mathrm{c}$ - lingual half of $\mathrm{M}^{1}$ crown about equal in length to or longer than buccal half, both halves separated from each other by anteroposterior constriction, $17 \mathrm{~d}$ - lingual half of $\mathrm{M}^{1}$ crown subequal in length to buccal half, no anteroposterior constriction between both halves; $18 \mathrm{a}$ - anterior and posterior cingula of $\mathrm{M}^{1}$ not continuous around lingual base of protocone, 18b-anterior and posterior cingula of $\mathrm{M}^{1}$ continuous around linul base of protocone; $19 \mathrm{a}-\mathrm{buccal}$ border of $\mathrm{M}^{2}$ crown situated behind buccal half of $\mathrm{M}^{1}$ and posteris then $\mathrm{P}^{4}$, $20 \mathrm{~b}-\mathrm{Mi}^{2}$ three-rooted and subequal in size to $\mathrm{P}^{4}, 20 \mathrm{c}-\mathrm{M}^{2}$ two-rooted, $20 \mathrm{~d}-\mathrm{M}^{2}$ single-rooted, 20e $-\mathrm{M}^{2}$ absent. 
is unique in possessing state $17 \mathrm{~b}$ that arose from $17 \mathrm{a}$ by reduction of the posterior part of the $\mathrm{M}^{1}$ talon and simultaneous enlargement of its anterior part. This transformation is well supported by the transitional pattern of $\mathrm{M}^{1}$, as observed in the earliest known representatives of Plesictis (MGL 42043 and MNHN LIM343). Configuration $17 \mathrm{c}$ is diagnostic of the Mustelinae. It evidently evolved from state $17 \mathrm{~b}$ as a result of the symmetric expansion of the talon of $\mathrm{M}^{1}$, accompanied by reduction of the metacone wing of this tooth. The pattern of $\mathrm{M}^{1}$ in Plesiogale, with the lingual half of the crown being still shorter than the buccal one, is a good example for a transitional stage between configuration $17 \mathrm{~b}$ and those shown by Paragale and other mustelines, in which the lingual half of the $\mathrm{M}^{\mathbf{1}}$ crown is always longer than the buccal one. Condition 17d (Potamotherium), though theoretically derivable from an arrangement equivalent to that of Plesictis, is interpreted here as having originated from state $17 \mathrm{a}$ in consequence of great reduction of the $\mathrm{M}^{1}$ metacone wing. This inference is supported by the lingual position of $M^{2}(19 \mathrm{~b})$ in Potamotherium, suggesting quite another pattern of upper molar reduction in this genus as compared to that of the non-pinniped mustelidans. Accordingly, state $17 \mathrm{a}$ is primitive; $17 \mathrm{~b}$ and $17 \mathrm{~d}$ independently arose from $17 \mathrm{a} ; 17 \mathrm{~b}$ gave rise to $17 \mathrm{c}$.

18. Occurrence of $\mathrm{M}^{1}$ lingual cingulum (Fig. 5) - Character state 18a is typical of the Feliformia, being variably present among canoids and amphicyonids (Springhorn 1977). It is unknown in ursidans, but occurs in some mustelidans, for instance in the earliest known procyonid Pseudobassaris and the earliest known mustelid Mustelictis. Hence condition 18a is considered plesiomorphic for the Mustelida; its alternative (18b) is derived.

19. Position of $\mathrm{M}^{2}$ (Fig. 5) - Among carnivorans possessing $\mathrm{M}^{2}$, the earliest pinnipeds are unique in having state $19 \mathrm{~b}$ (for discussion see Classification). Thus condition $19 \mathrm{a}$ is primitive; $19 \mathrm{~b}$ is derived.

20. Occurrence, size, and form of $\mathrm{M}^{2}$ (Fig. 5) - Within the Mustelida, configuration $20 \mathrm{~b}$ is exclusive of Ailurus and some procyonids. In most post-Paleogene representatives of the Ursida and Amphicyonidae, $\mathrm{M}^{2}$ is larger than $\mathrm{P}^{4}$. However, the Paleogene ursidans (Amphicynodon, Cirot and de Bonis 1992; Parictis, Clark and Guensburg 1972; Nothocyon, Wang and Tedford 1992; Cephalogale, de Beaumont 1965) and amphicyonids (Springhorn 1977), like the canoids, are characterized by arrangement 20a. This supports the view that configuration 20a is plesiomorphic for the Mustelida, and that condition 20b arose from 20a and is therefore apomorphic within this taxon. The remaining states of this character represent succeeding steps in reduction of $\mathrm{M}^{2}$ and, according to this tendency, can be ordered in linear sequence as follows: $20 \mathrm{a} \rightarrow 20 \mathrm{c} \rightarrow 20 \mathrm{~d} \rightarrow 20 \mathrm{e}$.

21. Occurrence and form of $P_{1}$ (Fig. 6) - Character state 21a is primitive; states $21 \mathrm{~b}$ and $21 \mathrm{c}$ are derived; $21 \mathrm{~b}$ is intermediary between 21a and 21c. For argumentation justifying these statements see discussion of character 12 .

22. Relation of $\mathrm{M}_{1}$ trigonid to talonid (Fig. 6) - Outgroup comparisons with the Ursida, Amphicyonidae, and Canoidea indicate that character state 22a is present in the Mustelida ancestrally, whereas its alternative (22b) is derived. 

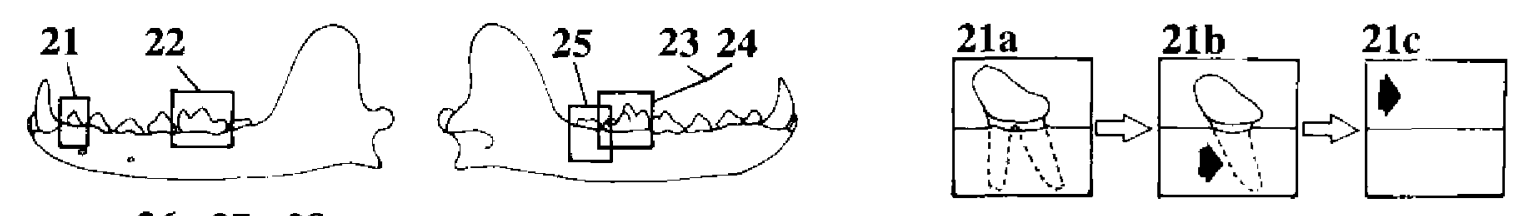

entoconulid

$\begin{array}{lll}26 & 27 & 28\end{array}$
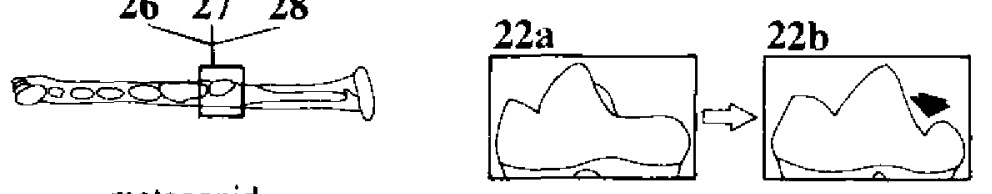

metaconid
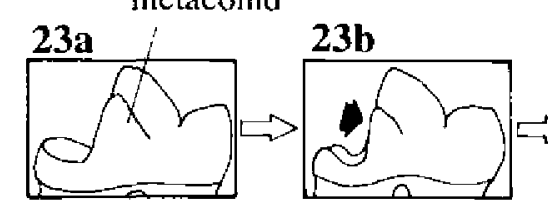

$23 \mathrm{c}$

23d
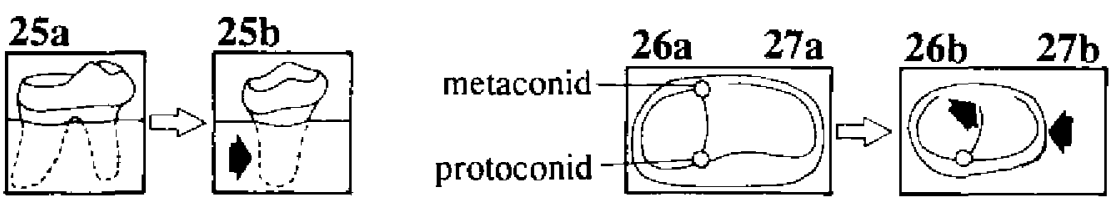

$24 \mathrm{~b}$

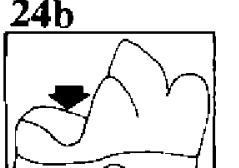

$24 c$

entoconid

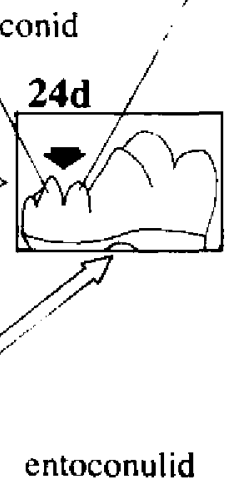

entoconulid

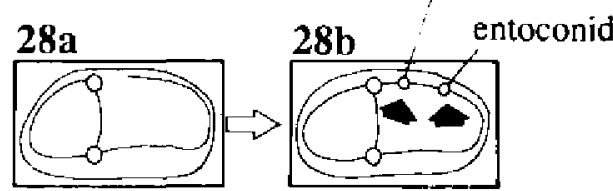

Fig. 6. Definitions of the states of characters 21-28 and the assigned polarity of their transformations in the early European mustelidans: 21a - $P_{1}$ two-rooted, 21b - $P_{1}$ single-rooted, 21c - $P_{1}$ absent; 22a - $M_{1}$ trigonid less than three times as long as talonid, $22 b-M_{1}$ trigonid more than three times as long as talonid; 23a - $\mathrm{M}_{1}$ metaconid distinctly higher than paraconid, $23 \mathrm{~b}-\mathrm{M}_{1}$ metaconid subequal in height to paraconid, 23c- $\mathrm{M}_{1}$ metaconid distinctly lower than paraconid, 23d - $M_{1}$ metaconid not differentiated; 24a $-\mathrm{M}_{1}$ entoconid and entoconulid poorly differentiated (ridge-like or cuspule-like), anterior and posterior halves of lingual wall of $\mathrm{M}_{1}$ talonid subequal in height to each other,

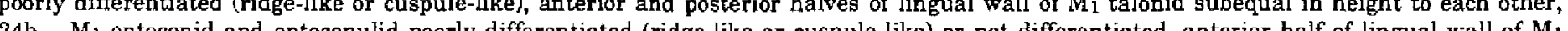
( talonid distinctly lower than posterior half, $24 \mathrm{c}-\mathrm{M}_{1}$ entoconid prominent (cusp-like), $\mathrm{M}_{1}$ entoconulid poorly differentiated (ridge-like or cuspule-like) or not differentiated, $24 \mathrm{~d}-\mathrm{M}_{1}$ entoconid and entoconulid prominent, cusp-like; $25 \mathrm{a}-\mathrm{M}_{2}$ two-rooted, $25 \mathrm{~b}-\mathrm{M}_{2}$ single-rooted; $26 a-M_{2}$ metaconid present, 26b - $M_{2}$ rnetaconid not differentiated; $27 a$ - talonid basin of $M_{2}$ distinctly longer than trigonid basin, $27 b-$ talonid and trigonid basins of $\mathrm{M}_{2}$ subequal in length; $28 \mathrm{a}-\mathrm{M}_{2}$ entoconid and entoconulid poorly differentiated (ridge-like or cuspule-like) or not differentiated, $28 \mathrm{~b}-\mathrm{M}_{2}$ entoconid and entoconulid prominent, cusp-like. 
23. Occurrence and size of $\mathrm{M}_{1}$ metaconid (Fig. 6) - The presence of state 23a in Paleogene amphicyonids (Springhorn 1977) and ursidans (Amphicynodon and Pachycynodon, Cirot 1992; Parictis, Clark and Guensburg 1972; Cephalogale, de Beaumont 1965) as well as its widespread distribution among Oligocene mustelidans (Table 1) support the conclusion that this state is plesiomorphic for the Mustelida. Character states $23 \mathrm{~b}, 23 \mathrm{c}$, and $23 \mathrm{~d}$ represent consecutive stages in reduction of the $\mathrm{M}_{1}$ metaconid and are regarded as derivative conditions. State $23 \mathrm{c}$ is unquestionably intermediate between $23 \mathrm{~b}$ and $23 \mathrm{~d}$.

24. Pattern of $M_{1}$ talonid (Fig. 6) - Most amphicyonids (Springhorn 1977) and the Paleogene ursidans (Amphicynodon and Pachycynodon, Cirot 1992; Parictis, Clark and Guensburg 1972; Cephalogale, de Beaumont 1965) display character state 24a. It is thus hypothesized to constitute the ancestral arrangement for the Mustelida. Condition $24 \mathrm{~b}$ is assumed to be derived from $24 \mathrm{a}$ by gradual decrease in height of the anterior part of the lingual wall of $\mathrm{M}_{1}$ talonid. This transformation seems to be associated with the anteroposterior contraction of the talonid, affecting all involved forms. State $24 \mathrm{c}$ is interpreted to have originated from $24 \mathrm{a}$ as a result of the enlargement of the entoconid. Configuration $24 \mathrm{~d}$ is derivable both from $24 \mathrm{a}$ by simultaneous increase in size of the entoconid and entoconulid and from 24c by enlargement of the entoconulid. Concluding, state $24 \mathrm{a}$ is primitive; $24 \mathrm{~b}$ and $24 \mathrm{c}$ represent independently derived conditions; $24 \mathrm{~d}$ arose from $24 \mathrm{a}$ or $24 \mathrm{c}$.

25. Number of $\mathrm{M}_{2}$ roots (Fig. 6) - Outgroup comparisons with the Ursida, Amphicyonidae, and Canoidea provide evidence that state 25a is retained by the mustelidans ancestrally, whereas $25 \mathrm{~b}$ is derived.

26. Occurrence of $\mathrm{M}_{2}$ metaconid (Fig. 6) - All ursidans and Oligocene mustelidans (Table 1) possess character state 26a. It is therefore considered primitive for the Mustelida; its alternative (26b) is derived.

27. Relation of $\mathrm{M}_{2}$ trigonid to talonid (Fig. 6) - Character state 27a occurs in many canoids and amphicyonids as well as in all ursidans. Hence it is assumed to be present in the Mustelida ancestrally; $27 \mathrm{~b}$ is thus an apomorphic condition.

28. Occurrence and form of $\mathrm{M}_{2}$ entoconid and entoconulid (Fig. 6) - Configuration $28 \mathrm{~b}$ is characteristic of Ailurus. Most other mustelidans, the Paleogene ursidans (Amphicynodon and Pachycynodon, Cirot 1992; Parictis, Clark and Guensburg 1972; Nothocyon, Wang and Tedford 1992; Cephalogale, de Beaumont 1965), the amphicyonids, and the canoids show character state 28a. Thus state 28a is considered ancestral for the Mustelida; $28 \mathrm{~b}$ represents the derived condition.

\section{Phylogenetic reconstruction}

Although the use of parsimony as an operational principle in scientific inference is justified, it is unclear which of various methods based on parsimony is the most appropriate for producing cladograms. It is often believed that minimum-step algorithms represent the only parsimonious procedures in cladistic analysis. In 
fact, however, Farris' (1983) definition of parsimony also provides the rationale for other methods, including character weighting and character compatibility analysis (Bryant 1989).

In contrast to numerical cladists, I believe that the monophyly of a group defined by the unanimous possession, among its members, of a single derived feature that does not also occur within two or more successive outgroups is better supported than one in which the members are united by a number of features that also occur in taxa outside of the group. Classifications of numerical cladists, resulting from minimum-step cladograms in which nodes are diagnosed by numerous unweighted features, are often subject to dramatic changes when a set of characters analyzed is altered; with regard to this, the most-recent classifications of the Carnivora (Wozencraft 1989 versus Wyss and Flynn 1993) may serve as a good example. On the contrary, a classification in which taxa are distinguished on the basis of single but "strong" derived features seems to be more stable.

For the above reasons, a character weighting procedure has been applied in the present approach to phylogeny of the Mustelida. Fig. 7 presents the outcome of an iterative process of generating, testing, and corroboration of subsequent hypotheses of the interrelationships among the early European mustelidans in order to find the topology that best accounts for the distribution of the analyzed character states among the 15 genera under study and in other known members of the Mustelida. In cases of conflicts among the 28 characters analyzed, the subjectively established 38 characters of the skull and dentition were also taken into account. Although the cladogram of Fig. 7 does not constitute the most parsimonious solution based exclusively on the character state matrix of Table 1 , it is believed to approach more reliably the real relationships within the Mustelida.

\section{Classification}

The principal objective of this study was to identify monophyletic taxa in the sense of Hennig (1966); paraphyletic and polyphyletic groups have been rejected. Apart from diagnoses based on apomorphies, phylogenetic definitions of taxa (de Queiroz and Gauthier 1990) are also provided. Although I am well aware that the corresponding supraspecific categories of the Linnaean system of hierarchy are not equivalent as commonly applied to groups of organisms (e.g., the family of mustelids versus the family of amphicyonids), I use their names in this classification because of their widely accepted usage; however, I do not introduce new names for "missing" categories. I have retained previously named taxa, and have left most previously unrecognized suprageneric taxa unnamed; the latter are informally referred to as Clades A, B, C, D, E, and F.

The proposed classification of 15 genera of early European mustelidans, reflecting the topology of the cladogram of Fig. 7 and the pattern of interrelationships among the outgroups, is presented below. 
362

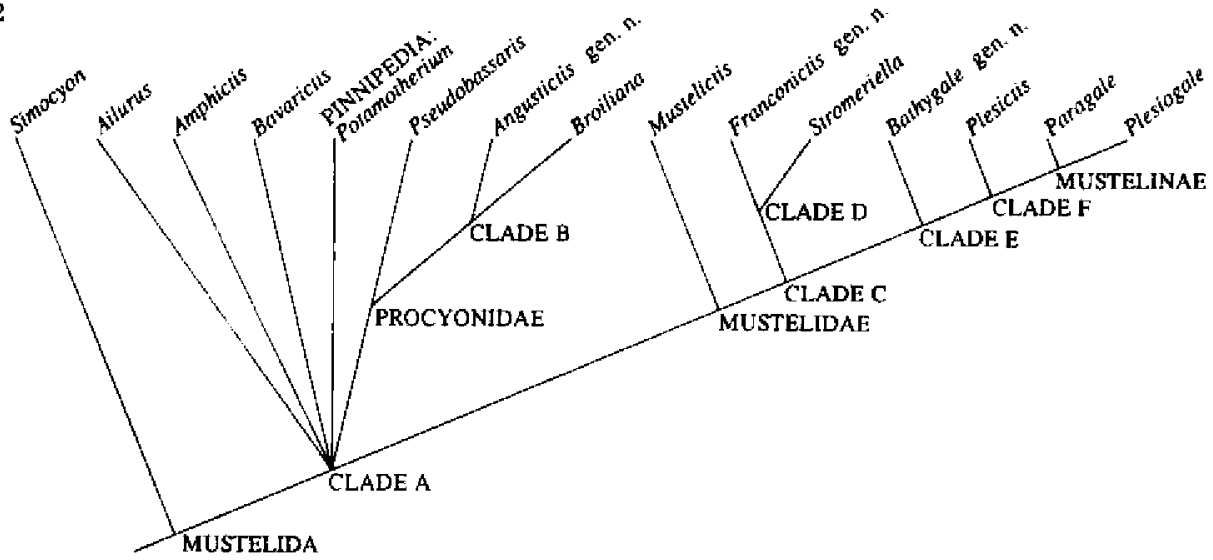

Fig. 7. Hypothesis of the phylogenetic relationships among the early European mustelidans based on an analysis of craniodental characters. Ailurus, Amphictis, Bavarictis, Pinnipedia, Procyonidae, and Mustelidoe are interpreted as originated independently from a common ancestral group within Clade A because no unique synapomorphy could be identified to give secure grounds for a hypothesis concerning interrelationships among these taxa.

The derived character states for the taxa are summarized below. Their definitions are provided in Figs 1-6. The character states inferred to be uniquely derived within the Arctoidea, and thus believed to constitute strong support for the suggested relationship, are denoted by exclamation marks. In each instance of variable occurrence of the alternative states in a terminal taxon, that of them which is regarded as derived within the taxon is given in parentheses. Asterisks indicate derived states that are present in the analyzed European genera included in a suprageneric taxon, but that are not considered synapomorphies for that suprageneric taxon, for example the genus Potamotherium versus the suprageneric taxon Pinnipedia. Reversals are designated by a negative sign preceding the character number.

Mustelida: $\mathrm{M}_{3}$ absent!

Simocyon: $3 \mathrm{~b}, 8 \mathrm{c}, 12 \mathrm{~b}(\mathrm{c}), 18 \mathrm{~b}, 21 \mathrm{~b}, 23 \mathrm{c}$

Clade A: $10 \mathrm{~b}$

Ailurus: $3 \mathrm{~b}, 5(\mathrm{~b}), 8 \mathrm{c}, 12 \mathrm{c}, 14 \mathrm{~b}, 15 \mathrm{~b}, 18 \mathrm{~b}, 20 \mathrm{~b}, 21 \mathrm{~b}(\mathrm{c}), 24 \mathrm{~d}, 28 \mathrm{~b}$

Amphictis: $3 \mathrm{~b}, 8(\mathrm{~b}), 12(\mathrm{~b}), 18 \mathrm{~b}, 20(\mathrm{c}), 21 \mathrm{~b}$

Bavarictis: $8 \mathrm{~b}, 12 \mathrm{~b}, 14 \mathrm{~b}, 16 \mathrm{~b}, 18 \mathrm{~b}, 20(\mathrm{c}), 21 \mathrm{~b}, 24 \mathrm{~b}, 27 \mathrm{~b}$

Pinnipedia - Potamotherium: 1b*, 3b*, 4b*, 6b, 7b, 8c*, 9b*, 12b, 16b*, 17d*, 18(b), 19b!, 20d*,

Procyonidae: $5 \mathrm{~b}, 7 \mathrm{~b}, 9 \mathrm{c} !$

$21 \mathrm{~b}, 22(\mathrm{~b}), 23(\mathrm{~b}), 24 \mathrm{~b}^{*}, 25 \mathrm{~b}^{*}, 27 \mathrm{~b}$

Pseudobassaris: 12b, 14b, 20(c), 21b, 24b, 27(b)

Clade B: $4 \mathrm{~b}, 18 \mathrm{~b}^{*}, 24 \mathrm{c}$

Angustictis gen. n.: 12b, 14b, 20c, 21(b)

Broiliana: 14(b), 21(b)

Mustelidae: $9 \mathrm{~d} !, 12 \mathrm{~b}, 21 \mathrm{~b}$

Mustelictis: 14b, 18(b), 20(c), 24(b), 27b

Clade C: $4 b, 5 b^{*}, 7 b, 8 b, 18 b^{*}$

Clade D: $11 \mathrm{~b}$

Franconictis gen. n.: 14b, 20c, 27b

Stromeriella: $7 \mathrm{c}$

Clade E: 2b!, 3b, 14b*, 20d, 23b, 24b, 27b

Bathygale gen. n.: 7(c), 20e, 22(b), 25(b)

Clade F: $17 \mathrm{~b}$ !

Plesictis: $-5(\mathrm{a}), 20(\mathrm{e}), 22(\mathrm{~b}), 25(\mathrm{~b})$

Mustelinae: $-2 \mathrm{a}, 7 \mathrm{c}, 9 \mathrm{e}, 11 \mathrm{~b}, 13 \mathrm{~b}, 16 \mathrm{~b}, 17 \mathrm{c}$ ! $20 \mathrm{e}, 22 \mathrm{~b}, 23 \mathrm{c}, 25 \mathrm{~b}$

Paragale: $8 \mathrm{c}, 21(\mathrm{c})$

Plesiogale: 12(c), 21c, 23d, 26b 


\section{Order Carnivora Bowdich 1821: 33}

$D$ e f i n it i o $n$ - The most recent common ancestral species of feliforms and caniforms and all of its descendants, plus all carnivorans that share an ancestral species with this clade, being not also common to the Creodonta.

D i a g n o s is - Eutherian mammals differing from all other Eutheria in the following derived features: $\mathrm{P}^{4}$ and $\mathrm{M}_{1}$ modified as the only carnassial teeth in the permanent dentition; $\mathrm{P}^{4}$ protocone situated anterolingual to the paracone.

\section{Suborder Caniformia Kretzoi 1945: 62}

$\mathrm{D}$ e f i $\mathrm{n}$ i $\mathrm{t}$ i o $\mathrm{n}$ - The most recent common ancestral species of canoids and arctoids and all of its descendants, plus all caniforms that share an ancestral species with this clade, being not also common to the Feliformia.

$\mathrm{D}$ i a $\mathrm{g} \mathrm{n}$ o $\mathrm{s}$ i s - Carnivorans differing from all other Carnivora in the derived enlargement and ramification of maxilloturbinals excluding nasoturbinals from the narial cavity.

Infraorder Arctoidea Flower 1869: 15

D e f i n it i o $n$ - The most recent common ancestral species of amphicyonids and arctomorphs and all of its descendants, plus all arctoids that share an ancestral species with this clade, being not also common to the Canoidea.

D i a g n o s i s - Caniforms differing from all other Caniformia in the derived enlargement of the inferior petrosal sinus and creation of the postscapular fossa.

Arctomorpha, new order-group taxon

(ranked between infraorder and category of taxon Mustelida)

$\mathrm{D}$ e f i $\mathrm{n}$ i t i o $\mathrm{n}$ - The most recent common ancestral species of ursidans and mustelidans and all of its descendants, plus all arctomorphs that share an ancestral species with this clade, being not also common to the Amphicyonidae.

$\mathrm{D}$ i a g $\mathrm{n}$ o $\mathrm{s}$ i s-Arctoids differing from all other Arctoidea in the derived creation of the suprameatal fossa. The absence of $\mathrm{M}^{3}$ is a supplementary synapomorphy of the Arctomorpha, evolved in some non-arctomorph arctoids independently.

D i s c u s s i on-Flynn et al. (1988: fig. 4,7) have recently presented three alternative hypotheses for the relationships of the amphicyonids within the Arctoidea: A, (Amphicyonidae, Ursida, Mustelida); B, ((Amphicyonidae, Ursida) Mustelida); and C, (Amphicyonidae (Ursida, Mustelida)). No synapomorphy supports hypothesis B; it must be therefore rejected. However, there are two synapomorphies supporting hypothesis $\mathrm{C}$ : presence of the suprameatal fossa and absence of $\mathrm{M}^{3}$. Although the suprameatal fossa occurs in some feliforms (Herpestides, Hunt 1991), it is absent in the canoids and amphicyonids (Springhorn 1976, Hunt 1977), which confirms its derivative nature for the taxon encompassing ursidans and mustelidans. The amphicyonids retained $\mathrm{M}^{3}$ that was subsequently lost in some later genera (Flynn $e$ $a l$. 1988). On the other hand, no ursidan or mustelidan is known to have $\mathrm{M}^{3}$. Thus the 
absence of this tooth may be considered a supplementary synapomorphy of the taxon Ursida plus Mustelida.

Though I am aware of the inconvenience of introducing a new order-group name, $I$ also feel the advantage of taking this action for facility of reference to the group including the ursidans and mustelidans, especially since its monophyly seems to be well supported.

\section{Order-group taxon Mustelida Tedford 1976: 372}

(ranked between categories of taxon Arctomorpha and Clade A)

D e f i n i t i o $\mathrm{n}$ - The most recent common ancestral species of Ailurus, pinnipeds, procyonids, and mustelids and all of its descendants, plus all mustelidans that share an ancestral species with this clade, being not also common to the Ursida.

D i a $\mathrm{g} \mathrm{n}$ o s i s - Arctomorphs differing from all other Arctomorpha in the derived loss of $\mathrm{M}_{3}$.

D i s c u s s i o n - Although it seems to be hardly probable that loss of $\mathrm{M}_{3}$ has occurred only once during arctomorph evolution, I follow here the diagnosis of Musteloidea as proposed by Schmidt-Kittler (1981) because of the absence of evidence to the contrary. I prefer the order-group name Mustelida to the family-group name Musteloidea to preserve the widely used name Pinnipedia, avoiding an infringement of the generally accepted convention that taxa of the higher categorical rank are not to be contained within taxa of the lower category.

\section{Genus Simocyon Wagner, 1858}

Pseudocyon Wagner 1857; 128 [not Pseudocyon Lartet 1851: 16].

Simocyon Wagner 1858: 366. Renaming of Pseudocyon Wagner, 1857.

Metarctos Gaudry 1860: 927. Type species - Gulo diaphorus Kaup 1832: 150, by monotypy. Synonymized with Simocyon Wagner, 1858 by Lydekker (1885: 145).

Amphalopex Kaup 1861: 15. Type species - Gulo diaphorus Kaup 1832: 150, by monotypy.

Pliocyon Thorpe 1921: 477 [not Pliocyon Matthew 1918: 190]. Type species - Pliocyon marshi Thorpe 1921: 477 , by monotypy.

Araocyon Thorpe 1922: 97. Renaming of Pliocyon Thorpe, 1921. Synonymized with Simocyon Wagner, 1858 by Zdansky (1924: 9 ).

Protursus Crusafont Pairó and Kurtén in Crusafont Pairó 1971: 155. Nomen nudum.

Protursus Crusafont Pairó and Kurtén in Crusafont Pairó 1973: 59. Nomen nudum.

Protursus Crusafont Pairó and Kurtén 1976: 22. Type species - Protursus simpsoni Crusafont Pairó and Kurtén 1976: 22, by original designation. Synonymized with Simocyon Wagner, 1858 by Thenius (1977: 40).

T y p e s p e i e s - Simocyon primigenius (Roth and Wagner, 1854) [Canis lupus primigenius Roth and Wagner in Wagner 1854: 339], by monotypy.

D i a g n o s i s (Fig. 7) - Mustelidans of a paraphyletic group that differs from all other Mustelida in the retention of the epitympanic recess that is not floored by the squamosal anterior to the fossa for the incudal processus brevis (Fig. 3: 10a); distinguished from other taxa of this paraphyletic group by the following autapomorphies: posterior border of the palate situated behind the posteriormost upper teeth (Fig. 2: 3b); meatal trough of ossified ectotympanic long, with its 
smallest mediolateral dimension greater than one-third of the bulla width (Fig. 2: 8c); $\mathrm{P}^{1}$ single-rooted or absent (Fig. $4: 12 \mathrm{~b}, \mathrm{c}$ ); anterior and posterior cingula of $\mathrm{M}^{1}$ continuous around the lingual base of the protocone (Fig. 5: 18b); $\mathrm{P}_{1}$ single-rooted (Fig. 6: 21b); $\mathrm{M}_{1}$ metaconid distinctly lower than the paraconid (Fig. 6: 23c).

D i s c u s s i o n - During most of its taxonomic history, Simocyon has subjectively been placed among either canoids or amphicyonids. De Beaumont (1964) was the first who suggested mustelidan affinities of this genus, including it within the Mustelidae, and later (1968) in the Procyonidae. Although none of the features mentioned by him can be regarded as mustelid synapomorphies, and those supporting the affiliation with the procyonids were erroneously assumed, I leave this genus within the Mustelida because of the absence of $\mathrm{M}_{3}$.

\section{Clade A}

(taxon unnamed, ranked between categories of taxa Mustelida and Pinnipedia)

D i a g n o s i s (Fig. 7) - Mustelidans differing from all other Mustelida in the derived configuration of the epitympanic recess the lateral part of which is floored by the squamosal anterior to the fossa for the incudal processus brevis (Fig. 3: 10b).

\section{Genus Ailurus F. Cuvier in Geoffroy Saint-Hilaire and Cuvier 1825: 3}

Arctaeliurus Gloger 1841: 55. Renaming of Ailurus Cuvier, 1825.

Aelurus Agassiz 1846: 9 [not Aelurus Klug 1842: 42]. Emendation of Ailurus Cuvier, 1825.

Parailurus Schlosser 1899: 73. Type species - Ailurus anglicus Dawkins 1888: 229, by monotypy. Ailurus Cuvier, 1825 and Parailurus Schlosser, 1899 are monotypic genera (Roberts and Gittleman 1984, Kurtén and Anderson 1980). Schlosser (1899) and Tedford and Gustafson (1977) provided evidence that Ailurus fulgens Cuvier, 1825 and Ailurus anglicus Dawkins, 1888 are sister species. Thus I synonymize Parailurus Schlosser, 1899 with Ailurus Cuvier, 1825, in order to maintain the monophyly of the latter taxon and make the taxonomy more informative by reducing the number of monotypic genera.

T y p e s peci e s-Ailurus fulgens Cuvier, 1825 [Ailurus Fulgens F. Cuvier in Geoffroy Saint-Hilaire and Cuvier 1825: 3], by monotypy.

$\mathrm{D}$ i a g n o s i s (Fig. 7) - Mustelidans of Clade A, distinguished from all other taxa included in this clade by the derived enlargement of the $\mathrm{P}^{4}$ hypocone that is prominent and subequal in size to the protocone (Fig. 5: 15b). Supplementary autapomorphies of Ailurus, presumed to be developed in some other taxa of Clade A independently, include the following features: posterior border of the palate situated behind the posteriormost upper teeth (Fig. 2: 3b); meatal trough of ossified ectotympanic long, with its smallest mediolateral dimension greater than one-third of the bulla width (Fig. 2: 8c); $\mathrm{P}^{1}$ absent (Fig. 4: 12c); $\mathrm{P}^{4}$ protocone conical: not formed by the cingulum entirely (Fig. 5: 14b); anterior and posterior cingula of $\mathrm{M}^{1}$ continuous around the lingual base of the protocone (Fig. 5: 18b); $\mathrm{M}^{2}$ three-rooted and subequal in size to $\mathrm{P}^{4}$ (Fig. 5: 20b); $\mathrm{P}_{1}$ single-rooted or absent (Fig. 6: $21 \mathrm{~b}, \mathrm{c}$ ); entoconid and entoconulid on $\mathrm{M}_{1}$ and $\mathrm{M}_{2}$ prominent, cusp-like (Fig. 6: 24d, 28b). 
D is c u s s i o n - The question of the affinities of Ailurus has been controversial since the discovery of the red panda. This genus has previously been considered an ursid or procyonid, grouped with Ailuropoda in their own family, or relegated to a monotypic family. Its phylogenetic relationships to other arctoids have recently been analyzed by Schmidt-Kittler (1981), Ginsburg (1982), Wozencraft (1989), Cirot (1992), and Wyss and Flynn (1993).

Schmidt-Kittler (1981: fig. 27) nested Ailurus within Musteloidea based on the absence of $\mathrm{M}_{3}$, regarding this genus as a living descendant of a paraphyletic group of stem musteloids. Cirot (1992: fig. 126) followed this assignment.

Ginsburg (1982: fig. 12) recognized Ailurus as a member of Ailuridae, being a sister group to the taxon encompassing ursids, Ailuropoda, and otariids (including Odobenus). However, his evidence for this relationship included no synapomorphies (Flynn et al. 1988).

Wozencraft (1989: fig. 18.2) placed Ailurus together with Ailuropoda and living ursids in Ursidae and interpreted them as the sister family to Otariidae (including Odobenus). For the so-constituted Ursoidea he proposed 10 features as synapomorphies. As shown in appendix 18.1 to Wozencraft's paper, five of them also occur within his Canoidea, a sister taxon to the Ursoidea. Below I make comments on the remaining five features, coded by him as $4(1), 23(1), 29(1), 39(1)$, and $40(1+2)$. Feature $4(1)$, or "posterior width of palate nearly equal to width at canines", is, in fact, of widespread occurrence among Wozencraft's Canoidea. Feature 23(1), or "petrosal widely separated from basioccipital", though present in otariids, is also seen in phocids and Potamotherium, being rare in ursidans and absent in Ailurus. Feature 29(1), or "ectotympanic not inflated", is plausibly primitive for the caniforms; besides, this bone in the mephitine and lutrine mustelids is not more inflated than that of Ailurus. Feature 39(1), or "hypomastoid fossa present", applies to many of Wozencraft's Canoidea but not to Ailurus. Feature $40(1+2)$, or "inferior petrosal sinus large" to "very large": this sinus is also relatively large in some fossil mustelidans (e.g., Stromeriella) and in Nasua and Potos.

Wozencraft (1989) recorded nine features to support his hypothesis of the monophyly of Ailurus, Ailuropoda, and extant ursids. However, only four of them, coded $8(1), 11(1), 20(1)$, and 78(1), were interpreted by Wozencraft as exclusive of the so-constituted Ursidae. Feature 8(1), or "lacrimal vestigial, restricted to area around lacrimal foramen": indeed, within Wozencraft's Ursidae the lacrimal is variable not only in size and occurrence but also in shape, enclosing the lacrimal foramen or constituting only a part of its border, when present; in mustelidans, this bone may be relatively large, surrounding the lacrimal foramen (e.g., Nasua), as in canids, or it is vestigial or lacking (e.g. otariids, Wyss 1987: 16). Feature 11, or "inferior oblique muscle fossa widely separated from lacrimal foramen" (0) or "closely adjacent to lacrimal foramen" (1), is variable in both Ailurus and ursids. Feature 20(1), or "suprameatal fossa present, dorsal to external meatus": in many arctoids, including the disputed Ursidae, the suprameatal fossa is placed both dorsal and posterodorsal to the external meatus, which corresponds exactly to 
Wozencraft's definition of feature 20(2), supposed by him to be exclusive of the procyonids. Feature $78(1)$, or " $\mathrm{M}^{2}$ hypocone present", is seen also in Broiliana, being of variable occurrence in Nasua and Procyon.

Wyss and Flynn (1993: fig. 4.3) paired Ailurus into a sister-group relationship with Ursida (including pinnipeds) on the basis of five hypothesized synapomorphies, coded by these authors $12(0), 16(2$ to 1$), 22(1), 29(0)$, and $47(1)$. There is no doubt that feature 12(0), or "alisphenoid canal present", has independently been lost at least several times within the Arctomorpha; however, no carnivoran lineage has hitherto been demonstrated to evidence the regeneration of this primitive condition convincingly. Feature 16, or "posterior entrance of carotid artery into auditory capsule: $1=$ posterior entry, artery enclosed in tube; $2=$ anterior entry, artery enclosed in osseous tube": both these conditions occur among mustelidans (Table 1, character states 5a and 5b). Wyss and Flynn (1993) interpreted the occurrence of feature 29(0), or "major a 4 arterial shunt absent", in their clades Ailurus plus Ursida and the mephitines plus lutrines as independent reversals; however, they provided no valid argument to support this statement. For comments on features 22(1), or "excavation in basioccipital accommodating inferior petrosal sinus large, excavation highly distinct", and $47(1)$, or " $\mathrm{M}^{2}$ hypocone present", see discussion of Wozencraft's features $40(1+2)$ and $78(1)$, above.

Concluding, Wozencraft (1989) and Wyss and Flynn (1993) presented no unequivocal synapomorphy to warrant the rejection of Schmidt-Kittler's (1981) hypothesis that Ailurus is a mustelidan.

\section{Genus Amphictis Pomel 1853: 99}

Ichneugales Jourdan 1861; 1012. Nomen nudum.

Ichneugales Jourdan 1862: 132. Nomen nudum.

lchneugale Jourdan in Filhol 1883: 69. Type species - Viverra leptorhyncha Filhol 1883; 67, by monotypy. Thenius (1949: 723) included "Cephalogale" gaillardi Wegner, 1913 in the synonymy of "Viverra" leptorhyncha Filhol, 1883. If Ichneugale Jourdan, 1883 were recognized, Amphictis

Pomel, 1853 would be paraphyletic. Thus I synonymize the former with the latter name and thereby avoid a paraphyletic taxon.

Alopecodon Viret 1933: 9 [not Alopecodon Broom 1908: 361]. Type species - Cephalogale Gaillardi Wegner 1913: 226, by original designation.

Viretius Kretzoi, 1947: 286. Renaming of Alopecodon Viret, 1933.

Alopecocyon Viret 1951: 23. Renaming of Alopecodon Viret, 1933

T y p e s p e $\mathrm{i}$ e s-Amphictis antiqua Pomel, 1853 [Amphictis antiquus Pomel 1853: 99], by subsequent designation of Dehm (1950: 60).

D i a g n o s i s - Mustelidans of Clade A, characterized by a combination of the following features: postorbital region shorter than broad (Fig. 1: 1a); sagittal crest present in adults, so that the dorsal cranial crests are $Y$-shaped (Fig. 1: 2a); posterior border of the palate situated behind the posteriormost upper teeth (autapomorphy; Figs 7 and 2: 3b); alisphenoid canal present (Fig. 2: 4a); posterior carotid foramen joined to the fossa leading to the posterior lacerate foramen (Fig. 2: 5a); posterior lacerate foramen smaller than the lateral opening of the external auditory meatus (Fig. 2: 6a); smallest width of the auditory bulla between the 
stylomastoid foramen and fossa leading to the posterior lacerate foramen smaller than the greatest diameter of the stylomastoid foramen (Fig. 2: 7a); meatal trough of ossified ectotympanic not differentiated or short, with its smallest mediolateral dimension smaller than one-third of the bulla width (Fig. 2: 8a, b); anterior and lateral walls of the suprameatal fossa neither excavated into the squamosal nor perpendicular to the roof of the external auditory meatus (Fig. 3: 9a); $\mathrm{P}^{1}$ two-rooted or single-rooted (Fig. 4: 12a, b); $\mathrm{P}^{4}$ carnassial notch present (Fig. 4: 13a); $\mathrm{P}^{4}$ protocone not differentiated or crescentic: completely formed by the cingulum (Fig. 5: 14a); $\mathrm{P}^{4}$ hypocone notably smaller than the protocone or absent (Fig. 5: 15a); $M^{1}$ not smaller than $P^{4}$ (Fig. 5: $16 a$ ); $M^{1}$ crown with its lingual half shorter than the buccal half, and the anterior and posterior borders of the lingual half being not parallel to each other (Fig. 5: 17a); anterior and posterior cingula of $\mathrm{M}^{1}$ continuous around the lingual base of the protocone (autapomorphy; Figs 7 and 5 : $18 \mathrm{~b}$ ); buccal border of the $\mathrm{M}^{2}$ crown positioned behind the buccal half of $\mathrm{M}^{1}$ (Fig. 5: 19a); $\mathrm{M}^{2}$ three-rooted or double-rooted, and distinctly smaller than $\mathrm{P}^{4}$ (Fig. 5: 20a, c); $P_{1}$ single-rooted (autapomorphy; Figs 7 and 6: 21b); $M_{1}$ trigonid less than three times as long as the talonid (Fig. 6: 22a); $M_{1}$ metaconid distinctly higher than the paraconid (Fig. 6: 23a); $\mathrm{M}_{1}$ entoconid and entoconulid poorly differentiated (ridge-like or cuspule-like), and the anterior and posterior halves of the lingual wall of the $\mathrm{M}_{1}$ talonid subequal in height to each other (Fig. 6: 24a); $\mathrm{M}_{2}$ double-rooted (Fig. 6: 25a); $M_{2}$ metaconid present (Fig. 6: 26a); talonid basin of $\mathrm{M}_{2}$ distinctly longer than the trigonid basin (Fig. 6: 27a); $\mathrm{M}_{2}$ entoconid and entoconulid poorly developed (ridge-like or cuspule-like) or not differentiated (Fig. 6: 28a).

$\mathrm{D}$ i s $\mathrm{c}$ u s s i o $\mathrm{n}$ - This genus has variously been referred to the viverrids (e.g., Pomel 1853), miacids (Pohle 1920), canids (e.g., Ginsburg 1961), amphicyonids (Ginsburg 1966), mustelids (e.g., de Bonis 1973), and procyonids (e.g., Roth 1987). Winge (1895) erected a new family with Amphictis as its type genus. De Bonis (1976) suggested that this genus was a representative of the ancestral stock of both the procyonids and mustelids. The phylogenetic arrangements of Schmidt-Kittler (1981: fig. 27) and Cirot (1992: fig. 126) nested Amphictis within Musteloidea (loss of $\mathrm{M}_{3}$ ) as one of the earliest offshoots from the main stem.

Genus Bavarictis Mödden 1991: 128

T y p e $\mathrm{s}$ p e c i e s-Bavarictis gaimersheimensis Mödden 1991: 129, by original designation.

$\mathrm{D}$ i a $\mathrm{g} \mathrm{n}$ o s i s - Mustelidans of Clade A, distinguished by a combination of the following features: postorbital region shorter than wide (Fig. 1: 1a); sagittal crest present in adults: the dorsal cranial crests Y-shaped (Fig. 1: 2a); posterior border of the palate situated at level of the posteriormost upper teeth (Fig. 2: 3a); alisphenoid canal present (Fig. 2: 4a); posterior carotid foramen joined to the fossa leading to the posterior lacerate foramen ( $F i g .2: 5 a)$; posterior lacerate foramen smaller than the lateral opening of the external auditory meatus (Fig. 2: 6a); 
smallest width of the auditory bulla between the stylomastoid foramen and fossa leading to the posterior lacerate foramen smaller than the greatest diameter of the stylomastoid foramen (Fig. 2: 7a); meatal trough of ossified ectotympanic short, with its smallest mediolateral dimension smaller than one-third of the bulla width (autapomorphy; Figs 7 and 2: 8b); anterior and lateral walls of the suprameatal fossa neither excavated into the squamosal nor perpendicular to the roof of the external auditory meatus (Fig. 3: 9a); postlateral sulcus of the brain absent (Fig. 4: 11a); $\mathrm{P}^{1}$ single-rooted (autapomorphy; Figs 7 and 4: 12b); $\mathrm{P}^{4}$ carnassial notch present (Fig. 4: 13a); $\mathrm{P}^{4}$ protocone conical: not formed by the cingulum entirely (autapomorphy; Figs 7 and 5: 14b); $\mathrm{P}^{4}$ hypocone absent (Fig. 5: 15a); $\mathrm{M}^{1}$ smaller than $\mathrm{P}^{4}$ (autapomorphy; Figs 7 and 5: $16 \mathrm{~b}$ ); $\mathrm{M}^{1}$ crown with its lingual half shorter than the buccal half, and the anterior and posterior borders of the lingual half being not parallel to each other (Fig. 5: 17a); anterior and posterior cingula of $\mathrm{M}^{1}$ continuous around the lingual base of the protocone (autapomorphy; Figs 7 and 5: $18 \mathrm{~b}$ ); buccal border of the $\mathrm{M}^{2}$ crown located behind the buccal half of $\mathrm{M}^{1}$ (Fig. 5: 19a); $\mathrm{M}^{2}$ having three or two roots and being distinctly smaller than $\mathrm{P}^{4}$ (Fig. 5: 20a, c); $P_{1}$ single-rooted (autapomorphy; Figs 7 and 6: 21b); $M_{1}$ trigonid less than three times as long as the talonid (Fig. 6: 22a); $\mathrm{M}_{1}$ metaconid distinctly higher than the paraconid (Fig. 6: 23a); $\mathrm{M}_{1}$ entoconid and entoconulid poorly differentiated (ridge-like or cuspule-like) or not differentiated, and the anterior half of the lingual wall of the $\mathrm{M}_{1}$ talonid distinctly lower than the posterior half (autapomorphy; Figs 7 and 6: 24b), $M_{2}$ double-rooted (Fig. 6: 25a); $M_{2}$ metaconid present (Fig. 6: 26a); talonid and trigonid basins of $\mathrm{M}_{2}$ subequal in length (autapomorphy; Figs 7 and 6: 27b); $M_{2}$ entoconid and entoconulid not differentiated (Fig. 6: 28a).

D i s c u s s i o n - Mödden (1991) followed Schmidt-Kittler (1981), who placed this genus in a paraphyletic stem group of Musteloidea.

$$
\text { Order-group Taxon Pinnipedia llliger 1811: } 138
$$

(ranked between category of Clade $A$ and superfamily)

D e f i n i t i o $n$ - The most recent common ancestral species of otariids, odobenids, and phocids, plus all of its descendants.

$\mathrm{D}$ i a g n o s i s (Fig. 7) - Mustelidans of Clade A, differing from all other taxa included in this clade in the derived displacement of $\mathrm{M}^{2}$ linguad (subsequently lost), making the buccal border of its crown positioned behind the lingual half of $\mathrm{M}^{1}$ (Fig. 5: 19b). Supplementary synapomorphies of the Pinnipedia, assumed to be developed in some other taxa of Clade A independently, include the following features: posterior lacerate foramen greatly enlarged, so that it is greater than the lateral opening of the external auditory meatus (Fig. 2: 6b); smallest width of the auditory bulla between the stylomastoid foramen and fossa leading to the posterior lacerate foramen greater than the greatest diameter of the stylomastoid foramen, and the posterior border of the caudal entotympanic situated in front of that of the fossa leading to the posterior lacerate foramen (Fig. 2: 7b); $P^{1}$ and $P_{1}$ 
single-rooted (Figs 4: 12b, 6: 21b); $\mathrm{M}_{2}$ talonid and trigonid basins subequal in length (Fig. 6: 27b).

D i s c u s s i o n - The controversy over pinniped origin(s) and relationships has extensively been discussed elsewhere (Wyss 1987, Flynn et al. 1988, Wozencraft 1989). The present paper provides a new support for the monophyly of this group, including it within the Mustelida based on the absence of $\mathrm{M}_{3}$ shared by all pinnipeds.

Among carnivorans, $\mathrm{M}^{2}$ with its buccal margin located behind the lingual half of $\mathrm{M}^{1}$ (Fig, 5: 19b) is exclusive of Kolponomos (Stirton 1960: fig. 3), or an enigmatic arctomorph of the earliest Miocene (Tedford et al. 1991); Amphicticeps (Matthew and Granger 1924: fig. 4), or a Late Oligocene arctomorph of elusive affinities (Schmidt-Kittler 1981); the enaliarctine otariids Enaliarctos (Mitchell and Tedford 1973: fig. 5A) and Pteronarctos (Barnes 1989: fig. 5); and Potamotherium (Savage 1957: pl. 1/a). This lingual displacement of $\mathrm{M}^{2}$ is evidently associated with a different pattern of posterior reduction in the tooth row as compared to that of other carnivorans. No pinniped is known to show the alternative state (Fig. 5 : 19a). It seems therefore that the hypothesis considering the lingual position of $\mathrm{M}^{2}$ to be synapomorphic for the Pinnipedia has sufficiently strong basis to be put forward in spite of the fact that most pinnipeds lack $\mathrm{M}^{2}$.

\section{Genus Potamotherium Geoffroy Saint-Hilaire, 1833}

potamotherium Geoffroy Saint-Hilaire 1833: 80 [not Potamotherium Gloger 1841: 127 ].

Lutrictis Pomel 1847: 380. Type species - lutra valletoni Geoffroy Saint-Hilaire 1833: 80, by monotypy.

Stephanodon von Meyer 1847: 183. Type species - Stephanodon Mombachensis von Meyer 1847: 183, by monotypy. Synonymized with Potamotherium Geoffroy Saint-Hilaire, 1833 by Gervais (1852, p. 11 in explanations to pls XXVI-XXVIII).

Potamophilus Gervais 1852: 2nd unnumbered page in explanations to pl. XXII |not Potamophilus Germar 1811; 41; not Potamophilus Latreille in Desmarest 1826: 97; not Potamophilus Muller 1838: 140]. Type species - lutra valletoni Geoffroy Saint-Hilaire 1833: 80, by monotypy.

T y p e s p e c i e s-Potamotherium valletoni (Geoffroy Saint-Hilaire, 1833) [lutra valletoni Geoffroy Saint-Hilaire 1833: 80], by monotypy.

D i a g n o s is - Pinnipeds distinguished from other members of the Pinnipedia by a combination of the following features: postorbital region greatly elongated in adults, longer than its greatest width (Fig. 1: 1b); posterior border of the palate situated behind the posteriormost upper teeth (Fig. 2: 3b); alisphenoid canal absent (Fig. 2: 4b); meatal trough of ossified ectotympanic long, with its smallest mediolateral dimension greater than one-third of the bulla width (Fig. 2: 8c); suprameatal fossa absent (Fig. 3: 9 b); $M^{1}$ smaller than $P^{4}$ (Fig. 5: $16 b$ ); $M^{1}$ crown broader buccolingually than long anteroposteriorly, with its lingual and buccal halves subequal in length to each other (autapomorphy; Figs 7 and $5: 17 d$ ); $M^{2}$ single-rooted (Fig. 5: 20d); $M_{1}$ metaconid higher than or subequal to the paraconid (Fig. 6: 23a, b); anterior half of the lingual wall of the $\mathrm{M}_{1}$ talonid distinctly lower than the posterior half (Fig. 6: 24b); $\mathrm{M}_{2}$ single-rooted (Fig. 6: 25b); $\mathrm{M}_{2}$ metaconid present (Fig. 6: 26a). 
D i s c u s s i o n-Most earlier students of Potamotherium grouped the genus with lutrines, although some of them (e.g., Savage 1957) paid attention to its morphological similarities to phocids. These resemblances induced Tedford (1976) to transfer this genus to the Phocidae. Schmidt-Kittler (1981) also excluded Potamotherium from the lutrines, based on the absence of the suprameatal fossa in the former; however, though he identified the corresponding arrangement in the auditory region of Phoca, he recognized Potamotherium as a separate offshoot of the musteloid stem group. The present paper supports the unique common ancestry of Potamotherium and phocids, as distinguished from all other pinnipeds by the derived loss of the alisphenoid canal.

\section{Family Procyonidae Gray 1825: 339}

D e f in it i o $\mathrm{n}$ - The most recent common ancestral species of Bassaricyon, Nasua, Nasuella, Potos, and Procyon, and all of its descendants.

D i a g n o S i S (Fig. 7)-Mustelidans of Clade A, distinguished from all other taxa included in this clade by the derived configuration of the suprameatal fossa the ventral extension of the medial wall of which is subequal to that of the lateral wall and at least its anterior or lateral wall is perpendicular to the roof of the external auditory meatus or excavated into the squamosal (Fig. 3: 9c). Supplementary synapomorphies of the Procyonidae, presumed to be developed in some other taxa of Clade A independently, include the following features: posterior carotid foramen separated from the fossa leading to the posterior lacerate foramen (Fig. 2: 5b); smallest width of the auditory bulla between the stylomastoid foramen and fossa leading to the posterior lacerate foramen greater than the greatest diameter of the stylomastoid foramen, and the posterior border of the caudal entotympanic situated in front of that of the fossa leading to the posterior lacerate foramen (Fig. 2: $7 \mathrm{~b}$ ).

D i s c us s i o n - After the description of the suprameatal fossa in Procyon, Potos, and Bassariscus by Segall (1943), this structure was often employed, especially recently, to diagnose the Procyonidae. At first, the presence of the fossa was regarded as characteristic of this family (e.g., Hough 1948); later, its deepness in procyonids was contrasted with the shallowness seen in many other arctomorphs (e.g., Schmidt-Kittler 1981). The present paper provides another attempt to define states of this character (Fig. 3: 9a-e), to use them at distinguishing the major mustelidan clades. According to these definitions, the procyonids are the only arctoids that possess state $9 \mathrm{c}$.

Numerous other features of the skull and dentition have recently been proposed to support the monophyletic status of the procyonids (Baskin 1982, 1989, Ginsburg 1982, Cirot 1988, 1992, Flynn et al. 1988, Wozencraft 1989, Decker and Wozencraft 1991, Wyss and Flynn 1993). All of them, however, also occur within the non-procyonid Mustelida and seem to be, therefore, of less relevance to the question of the relationship advocated here. 
Genus Pseudobassaris Pohle 1917: 408

T y p e s p e c i e s - Pseudobassaris riggsi Pohle 1917: 409, by original designation.

D i a g n o s is (Fig. 7) - Procyonids differing from all other Procyonidae in the retention of the alisphenoid canal (Fig. 2: 4a) and in the autapomorphically developed $M_{1}$, in which the entoconid and entoconulid are poorly differentiated (ridge-like or cuspule-like) or not differentiated and the anterior half of the lingual wall of the talonid is distinctly lower than the posterior half (Fig. 6: 24b). Supplementary autapomorphies of Pseudobassaris, derived by some other procyonids independently, include the following features: $P^{1}$ and $P_{1}$ single-rooted (Figs $4: 12 b$, 6: $21 \mathrm{~b}$ ); $\mathrm{P}^{4}$ protocone conical: not formed by the cingulum entirely (Fig. 5: $14 \mathrm{~b}$ ).

D i s c u s s i o n - Pohle (1917) described this genus as a procyonid, mainly because of its believed resemblance to Bassariscus. Subsequent systematists consistently doubted this placement (e.g., Simpson 1945: 226). Hough (1948) included Pseudobassaris in Plesictis while Schmidt-Kittler (1981) synonymized it with Mustelictis. Mödden (1991) pointed out that the suprameatal fossa in Pseudobassaris is deep, whereas that of Mustelictis is shallow, and treated both the genera separately; however, he did not suggest their relationships. I follow the original allocation of Pseudobassaris to the Procyonidae because this genus shares the unique synapomorphy of the family.

\section{Clade B}

(taxon unnamed, ranked between family and genus)

D i a g n o s is (Fig. 7) - Procyonids differing from all other Procyonidae in the following derived features: alisphenoid canal absent (Fig. 2: 4b); $\mathrm{M}_{1}$ entoconid prominent (cusp-iike) while $\mathrm{M}_{1}$ entoconulid poorly developed (ridge-like or cuspule-like) or not differentiated (Fig, 6: 24c).

\section{Angustictis, new genus}

T y p e s p e c i e s-Angustictis mayri (Dehm, 1950) [Plesictis mayri Dehm 1950: 46].

E t y m o log y - Latin angustus, narrow, and ictis (Greek ïkť̌), weasel-like carnivorous animal; in allusion to great transverse elongation of the upper molars; feminine in gender.

$\mathrm{D}$ i a g n o s i s - Procyonids of Clade B, distinguished by a combination of the following features: posterior border of the palate situated at level of the posteriormost upper teeth (Fig. 2: 3a); $\mathrm{P}^{1}$ single-rooted (autapomorphy; Figs 7 and 4: 12b); $\mathrm{P}^{4}$ protocone conical: not formed by the cingulum entirely (autapomorphy; Figs 7 and 5: 14b); $\mathrm{P}^{4}$ hypocone absent (Fig. 5: 15a); anterior and posterior cingula of $\mathrm{M}^{1}$ continuous around the lingual base of the protocone (Fig. 5: 18b); $\mathrm{M}^{2}$ two-rooted (autapomorphy; Figs 7 and 5: 20c). 
Angustictis gen. n. differs from Broiliana in the following features: $\mathrm{P}^{1}$ single-rooted; $\mathrm{P}^{4}$ protocone wing proportionally smaller; $\mathrm{M}^{1}$ shorter relative to its width; $M^{1}$ parastyle wing better developed while $M^{1}$ metacone wing less well developed; metaconule on $\mathrm{M}^{1}$ vestigial or absent; $\mathrm{M}^{1}$ hypocone not differentiated; $\mathrm{M}^{2}$ smaller relative to $\mathrm{M}^{1}$ and $\mathrm{P}^{4}$, double-rooted, with a less complicated occlusal pattern; $\mathrm{M}_{2}$ smaller relative to $\mathrm{M}_{1}$.

Genus Broiliana Dehm 1950: 80

T y p e s pe ci e s-Broiliana nobilis Dehm 1950: 81 , by original designation.

$\mathrm{D}$ i a g n o s i s-Procyonids of Clade B, characterized by a combination of the following features: posterior border of the palate situated at level of the posterior-most upper teeth (Fig. 2: 3a); meatal trough of ossified ectotympanic not differentiated (Fig. 2: 8a); $\mathrm{P}^{1}$ two-rooted (Fig. 4: 12a); $\mathrm{P}^{4}$ hypocone considerably smaller than the protocone or not differentiated (Fig. 5: 15a); anterior and posterior cingula of $M^{1}$ continuous around the lingual base of the protocone (Fig. $5 ; 18 \mathrm{~b}$ ); $\mathrm{M}^{2}$ three-rooted and distinctly smaller than $\mathrm{P}^{4}$ (Fig. 5: 20a); $\mathrm{M}_{1}$ metaconid distinctly higher than the paraconid (Fig. 6: 23a).

Broiliana differs from Angustictis gen. $n$. in the following features: $\mathrm{P}^{1}$ double-rooted; $\mathrm{P}^{4}$ protocone wing proportionally larger; $\mathrm{M}^{1}$ longer relative to its width; $\mathbf{M}^{1}$ parastyle wing less well developed while $\mathbf{M}^{1}$ metacone wing better developed; metaconule and hypocone on $M^{1}$ prominent; $M^{2}$ larger relative to $M^{1}$ and $P^{4}$, three-rooted, with a more complicated occlusal pattern; $\mathbf{M}_{2}$ larger relative to $\mathbf{M}_{1}$.

D i s c u s s i o n-Broiliana was originally classified by Dehm (1950) as a meline mustelid in its own tribe. De Beaumont (1964) rose this tribe to the subfamily level within the Mustelidae, and later (1968) moved it to the Procyonidae on the basis of morphological similarities in the auditory region. The incorporation of Broiliana in the procyonids has been followed by most subsequent students of this genus.

Family Mustelidae Fischer von Waldheim 1817: 372

$\mathrm{D}$ e f i n i t i o n - The most recent common ancestral species of Bassariscus, mephitines, lutrines, melines, and mustelines (including mellivorines), and all of its descendants.

Di a g n o s is (Fig. 7) - Mustelidans of Clade A, differing from all other taxa included in this clade in the derived configuration of the suprameatal fossa the medial wall of which is absent or its ventral extension is considerably smaller than that of the lateral wall and at least its anterior or lateral wall is perpendicular to the roof of the external auditory meatus or excavated into the squamosal (Fig. 3: $9 \mathrm{~d}$ ). The single-rooted $\mathrm{P}^{1}$ and $\mathrm{P}_{1}$ (Figs $4: 12 \mathrm{~b}, 6: 21 \mathrm{~b}$ ) are supplementary synapomorphies of the Mustelidae, presumed to be developed in some other taxa of Clade A independently.

D i s c u s s i o n - Several features have been employed to support the monophyly of the Mustelidae (Tedford 1976, Schmidt-Kittler 1981, Qiu and Schmidt- 
-Kittler 1982, de Muizon 1982, Cirot 1988, 1992, Flynn et al. 1988, Wozencraft 1989, Wyss and Flynn 1993); however, their synapomorphic status has been questioned, directly or indirectly, by other investigators (Schmidt-Kittler 1981, Wiig 1983, Wyss 1987, Wozencraft 1989 , Wyss and Flynn 1993). I discuss below two of these features, the notchless shearing blade of $P^{4}$ (Wortman 1901) and the ventrally closed suprameatal fossa (Schmidt-Kittler 1981), because they seem to be best founded. The former feature has generally been accepted as the unquestionable synapomorphy of the mustelids; no objective argument has hitherto been presented contrary to the latter feature.

The carnassial notch on $\mathrm{P}^{4}$ has independently been lost at least four times during mustelid evolution: within the Mephitinae, as evidenced by its retention in Miomephitis and Palaeomephitis (= Trochotherium) of the European Miocene and in Mydaus (= Suillotaxus); within the Lutrinae, as indicated by its occurrence in Enhydra; among leptarctines (Qiu and Schmidt-Kittler 1982); and in the mustelines. Thus this feature cannot be regarded as a synapomorphy of the Mustelidae.

The suprameatal fossa that is partially or completely closed anteriorly by the posterior wall of auditory tube is exclusive of the mustelines, lutrines, melines, and leptarctines (Schmidt-Kittler 1981, Qiu and Schmidt-Kittler 1982). Even if the mustelines, lutrines, and melines indeed constitute the monophyletic grouping as suggested by Schmidt-Kittler (1981, 1984) and Qiu and Schmidt-Kittler (1982), the sister-group relationship of the so-constituted clade with the Leptarctinae appears to be uncertain. On the other hand, the disputed feature excludes from the Mustelidae a number of genera that are plausibly related to the ancestors of both leptarctines and modern mustelids, leaving them within a paraphyletic assemblage. It seems, therefore, to be sufficiently warranted to rediagnose this family, with the 9d suprameatal fossa (Fig. 3) as the major synapomorphy, especially insofar as this feature is evidently uniquely derived within the Caniformia.

Genus Mustelictis Lange 1969: 2870

T y p e s p e c i e s-Mustelictis piveteaui Lange 1969: 2870, by monotypy.

D i a g n o s i s (Fig. 7) - Mustelids of a paraphyletic group that differs from all other Mustelidae in retaining the following plesiomorphies: the alisphenoid canal present (Fig. 2: 4a), the smallest width of the auditory bulla between the stylomastoid foramen and fossa leading to the posterior lacerate foramen smaller than the greatest diameter of the stylomastoid foramen (Fig. 2: 7a), and the meatal trough of ossified ectotympanic not differentiated (Fig. 2: 8a); distinguished from other taxa of this paraphyletic group by the following autapomorphies: $\mathrm{P}^{4}$ protocone conical, not formed by the cingulum entirely (Fig. 5: 14b); talonid and trigonid basins of $\mathrm{M}_{2}$ subequal in length (Fig. 6: 27b).

D i s c u s s i o n - Lange $(1969,1970)$ recognized Mustelictis as a musteline. Schmidt-Kittler (1981) and Cirot (1992) considered it as an early musteloid offshoot of the ancestral stock of procyonids and mustelids. 


\section{Clade C}

(taxon unnamed, ranked between family and higher of categories

$$
\text { of Clades D and E) }
$$

D i a g n o s i s (Fig. 7) - Mustelids distinguished from all other Mustelidae by the following derived features: alisphenoid canal absent (Fig. 2: 4b); smallest width of the auditory bulla between the stylomastoid foramen and fossa leading to the posterior lacerate foramen greater than the greatest diameter of the stylomastoid foramen, and the posterior border of the caudal entotympanic situated in front of that of the fossa leading to the posterior lacerate foramen (Fig. 2: 7b); meatal trough of ossified ectotympanic short, with its smallest mediolateral dimension smaller than one-third of the bulla width (Fig. 2: $8 \mathrm{~b}$ ).

\section{Clade D}

(taxon unnamed, ranked between category of Clade $\mathrm{C}$ and genus)

D i a g n o s i s (Fig. 7) - Mustelids of Clade C, belonging to a paraphyletic group that differs from all other taxa included in Clade $\mathrm{C}$ in having the following features: posterior border of the palate situated at level of the posteriormost upper teeth (Fig. 2: 3a); $\mathrm{M}^{2}$ with three to two roots (Fig. 5: 20a, c); $\mathrm{M}_{1}$ metaconid distinctly higher than the paraconid (Fig. 6: 23a); anterior and posterior halves of the lingual wall of the $M_{1}$ talonid subequal in height to each other (Fig. 6: 24a). The derived creation of the postlateral sulcus on the brain (Fig. 4: 11b) distinguishes members of Clade D from all other taxa of this paraphyletic group.

\section{Franconictis, new genus}

T y p e s p e c i e s - Franconictis humilidens (Dehm, 1950) [Plesictis? humilidens Dehm 1950: 54].

E t y m o log y - After the medieval duchy Franconia, including the area from where the type species of the genus was described; Latin ictis (Greek íkrǐ), weasel-like carnivorous animal; feminine in gender.

D i a g n o s i s (Fig. 7) - Mustelids of Clade D, distinguished from other representatives of this clade by the following autapomorphies: $\mathrm{P}^{4}$ protocone conical, not formed by the cingulum entirely (Fig. 5: 14b); $\mathrm{M}^{2}$ two-rooted (Fig. 5: 20c); $\mathrm{M}_{2}$ talonid and trigonid basins subequal in length (Fig. 6: 27b).

Franconictis gen. n. differs from Stromeriella in the following features: infraorbital foramina relatively smaller; braincase about as high as the occiput; auditory bullae less well inflated and subtriangular in outline, with a better developed meatal tube; caudal entotympanic expanded posteriorad less extensively (Fig. 2: $7 \mathrm{~b}$ ); medial wall of the suprameatal fossa less well developed; lateral extension of the anterior part of the epitympanic recess into squamosal less extensive while its dorsal excavation into petrosal wider; $\mathrm{P}^{4}$ protocone wing proportionally smaller, with a conical protocone (Fig. 5: $14 \mathrm{~b}$ ); $\mathrm{M}^{1}$ shorter relative to its width; $\mathrm{M}^{1}$ parastyle 
wing better developed while $M^{1}$ metacone wing less well developed; $M^{2}$ smaller relative to $\mathrm{M}^{1}$ and $\mathrm{P}^{4}$, double-rooted, with a less complicated occlusal pattern; $\mathbf{M}_{1}$ talonid smaller relative to the trigonid; talonid basin of $\mathrm{M}_{2}$ about equal in length to the trigonid basin (Fig. 6: 27b).

Genus Stromeriella Dehm 1950: 99

T y p e s p e c i e s-Stromeriella franconica Dehm 1950: 100, by original designation.

D i a g n o s i s (Fig. 7) - Mustelids of Clade D, distinguished from other members of this clade by the autapomorphically expanded caudal entotympanic that terminates posteriorly behind the fossa leading to the posterior lacerate foramen (Fig. 2: 7c).

Stromeriella differs from Franconictis gen. $\mathrm{n}$. in the following features: infraorbital foramina relatively larger; braincase distinctly higher than the occiput; auditory bullae better inflated and subellipsoidal in outline, with a less well developed meatal tube; caudal entotympanic expanded posteriorad more extensively (Fig. 2: 7c); medial wall of the suprameatal fossa better developed; lateral excavation of the anterior part of the epitympanic recess into squamosal more spacious while its dorsal extension into petrosal less extensive; $\mathrm{P}^{4}$ protocone wing proportionally larger, with a crescentic protocone (Fig. 5: 14a); $\mathbf{M}^{1}$ longer relative to its width; $M^{1}$ parastyle wing less well developed while $\mathbf{M}^{1}$ metacone wing better developed; $\mathrm{M}^{2}$ larger relative to $\mathrm{M}^{1}$ and $\mathrm{P}^{4}$, three-rooted, with a more complicated occlusal pattern; $\mathrm{M}_{1}$ talonid larger relative to the trigonid; talonid basin of $\mathrm{M}_{2}$ distinctly longer than the trigonid basin (Fig. 6: 27a).

D i s c u s s i o n - Dehm (1950) allied Stromeriella with Broiliana and placed them among melines. De Beaumont (1964) excluded these genera from the Melinae, and later (1968) concluded that they are procyonids based on the comparison of their auditory regions with that of Bassariscus. Most subsequent authors have accepted the inclusion of Stromeriella in the Procyonidae. The present paper, however, unites this genus with the Mustelidae, principally because of the condition of the suprameatal fossa.

\section{Clade E}

(taxon unnamed, ranked between categories of Clades $\mathrm{C}$ and $\mathrm{F}$ )

D i a g n o s i s (Fig. 7) - Mustelids of Clade C, differing from all other taxa included in this clade in the following derived features: strong parasagittal crests present in adults, so that the dorsal cranial crests are parallel to X-shaped (Fig. 1: $2 \mathrm{~b}$ ); posterior border of the palate situated behind the posteriormost upper teeth (Fig. 2: $3 \mathrm{~b}$ ); $\mathrm{M}^{2}$ single-rooted (Fig. 5: 20d); $\mathrm{M}_{1}$ metaconid subequal in height to the paraconid (Fig. 6: 23b); anterior half of the lingual wall of the $M_{1}$ talonid distinctly lower than the posterior half (Fig. 6: 24b); $\mathrm{M}_{2}$ talonid and trigonid basins subequal in length (Fig. 6: 27b). 


\section{Bathygale, new genus}

T y p e s p e c i e - Bathygale lemanensis (Pomel, 1853) [Plesictis lemanensis Pomel 1853: 97].

E t y m o I o g y - Greek $\beta \alpha \theta u ́$, deep, and $\gamma \alpha \lambda \dot{n} \eta$ or $\gamma \alpha \lambda \hat{\eta}$, small carnivorous animal; in reference to great dorsal extension of the epitympanic recess; feminine in gender.

D i a g n o s i s - Mustelids of Clade E, distinguished by a combination of the following features: posterior carotid foramen separated from the fossa leading to the posterior lacerate foramen (Fig. 2: $5 \mathrm{~b}$ ); absence of the postlateral sulcus on the brain surface (Fig. 4: 11a); $\mathrm{P}^{4}$ carnassial notch present (Fig. 4: 13a); $\mathrm{P}^{4}$ protocone conical: not formed by the cingulum entirely (Fig. 5: 14b); $\mathrm{P}^{4}$ hypocone absent (Fig. 5: 15a); $\mathrm{M}^{1}$ not smaller than $\mathrm{P}^{4}$ (Fig. 5: 16a); lingual half of the $\mathrm{M}^{1}$ crown shorter than the buccal half, and the anterior and posterior borders of the lingual half not parallel to each other (Fig. 5: 17a); $\mathrm{M}^{2}$ absent (autapomorphy; Figs 7 and 5: 20e); $M_{2}$ metaconid present (Fig. 6: 26a).

Bathygale gen. n. differs from Plesictis in the following features: anterior and posterior margins of the lingual half of $\mathrm{M}^{1}$ not parallel to each other, and the posterolingual portion of the $\mathbf{M}^{1}$ cingulum better developed than the anterolingual one (Fig. 5: 17a); auditory bullae better inflated (autapomorphy) and less compressed mediolaterally; anterior part of the epitympanic recess expanded dorsad into the petrosal more extensively (autapomorphy).

\section{Clade F}

(taxon unnamed, ranked between category of Clade $\mathrm{E}$ and subfamily)

D i a g n o s i s (Fig. 7) - Mustelids of Clade E, differing from all other taxa included in this clade by the derived configuration of $\mathrm{M}^{\mathbf{1}}$, in which the lingual half of the crown is shorter than the buccal half, and the anterior and posterior borders of the lingual half are parallel to each other (Fig. 5: 17b).

\section{Genus Plesictis Pomel 1846b: 366}

Plesictis Pomel 1846a: 199. Nomen nudum.

T y p e s p ec i e s-Plesictis plesictis (de Laizer and de Parieu, 1839) [Martes plesictis de Laizer and de Parieu in Anonymous 1839: 43], by monotypy.

$\mathrm{D}$ i a $\mathrm{g} \mathrm{n}$ o s i s - Mustelids of Clade F, distinguished by a combination of the following features: postlateral sulcus of the brain absent (Fig. 4: 11a); $P^{4}$ carnassial notch present (Fig. 4: 13a); $\mathrm{P}^{4}$ protocone conical: not formed by the cingulum entirely (Fig. 5: 14b); $\mathrm{P}^{4}$ hypocone absent (Fig. 5: 15a); $\mathrm{M}^{1}$ not smaller than $\mathrm{P}^{4}$ (Fig. 5: 16a); $\mathrm{M}_{2}$ metaconid present (Fig. 6: 26a).

Plesictis differs from Bathygale gen. $\mathrm{n}$. in the following features: anterior and posterior borders of the lingual half of $\mathrm{M}^{1}$ parallel to each other, and the anterolingual and posterolingual portions of the cingulum subequal to each other in development (Fig. 5: 17b); auditory bullae more compressed mediolaterally (autapomorphy) and 
less well inflated; anterior part of the epitympanic recess excavated dorsad into the petrosal less extensively.

D i s c u s i o n-The earliest students of Plesictis (e.g., Pomel 1853) regarded it as a viverrid, but most later authors associated this genus with mustelids. Hough (1948) was the first to suggest placement of Plesictis in the Procyonidae because of a deep suprameatal fossa. Although some subsequent workers, particularly in recent years (e.g., Roth 1987), have followed this assignment, others did not accept it (e.g., Lavocat 1952).

Subfamily Mustelinae Fischer von Waldheim 1817: 372

D e f i n iti o n - The most recent common ancestral species of Eira, Galictis, Gulo, Ictonyx, Lyncodon, Martes, Mellivora, Mustela, Poecilictis, Poecilogale, and Vormela and all of its descendants.

$\mathrm{D}$ i a $\mathrm{g} \mathrm{n}$ o $\mathrm{s}$ i s (Fig. 7) - Mustelids of Clade F, differing from all other taxa included in this clade by the following derived features: sagittal crest present in adults, so that the dorsal cranial crests are Y-shaped (reversal; Fig. 1: 2a); posterior border of the caudal entotympanic situated behind that of the fossa leading to the posterior lacerate foramen (Fig. 2: 7c); lateral part of the suprameatal fossa partially closed by the posterior wall of the meatal tube anteriorly (Fig. 3: 9e); postlateral sulcus of the brain present (Fig. 4: 11b); $\mathrm{P}^{4}$ carnassial notch absent (Fig. 4: 13b); $\mathrm{M}^{1}$ smaller than $\mathrm{P}^{4}$ (Fig. 5: $16 \mathrm{~b}$ ); lingual half of the $\mathrm{M}^{1}$ crown about equal in length to or longer than the buccal one, and both the halves separated from each other by an anteroposterior constriction (Fig. 5: 17c); $\mathrm{M}_{1}$ metaconid distinctly lower than the paraconid (Fig. 6: 23c). Supplementary synapomorphies of the Mustelinae, evolved in some other taxa of Clade $\mathrm{F}$ independently, include the following features: $M^{2}$ absent (Fig. 5: 20e); $M_{1}$ trigonid more than three times as long as the talonid (Fig. 6: 22b); $\mathrm{M}_{2}$ single-rooted (Fig. 6: 25b).

Genus Paragale Petter 1967: 19

T y p e s p e c i e s - Paragale huerzeleri Petter, 1967 [Paragale hürzeleri Petter 1967: 19], by monotypy.

D i a g n o s i s (Fig. 7) - Mustelines differing from all other Mustelinae except Plesiogale in the retention of the suprameatal fossa that is only partially closed by the posterior wall of the meatal tube anteriorly (Fig. 3: 9e); characterized by the autapomorphically elongated meatal trough of ossified ectotympanic, making its smallest mediolateral dimension greater than one-third of the bulla width (Fig. 2: 8c), and the plesiomorphically retained metaconid on $\mathrm{M}_{2}$ (Fig, 6: 26a).

D i s c u s s i o n - Petter (1967) described Paragale as a mustelid, and de Muizon (1982) affiliated it to the Mustelinae.

Genus Plesiogale Pomel 1847: 380

T y p e s p e c i e s-Plesiogale angustifrons Pomel 1847: 385, by monotypy.

$\mathrm{D}$ i a g n o s i s (Fig. 7) - Mustelines differing from all other Mustelinae in $\mathrm{M}^{1}$ the trigon of which is plesiomorphically longer than the talon, and from all other 
mustelines but not Paragale in the retention of the suprameatal fossa that is only partially closed by the posterior wall of the meatal tube anteriorly (Fig. 3: 9e); distinguished by the autapomorphically lost $P_{1}$ (Fig. 6: 21c) and metaconid on both $M_{1}$ and $M_{2}$ (Fig. 6: 23d, 26b).

D i s c u s s i o n - This genus, though confused with Palaeogale during almost the half of its taxonomic history (Simpson 1946), has consistently been classified in the Mustelidae, being usually assigned to the mustelines.

Acknowledgments: I am grateful to R. L. Cifelli, Z. Kielan-Jaworowska, C. Mödden, M. Morlo, Z. Pucek, N. Schmidt-Kittler, R. H. Tedford, and L. Werdelin for constructive comments on an earlier version of this paper. For access to specimens in their care, I thank R. Angermann, B. Engesser, V. Fahlbusch, O. Fejfar, K. Fischer, L. Ginsburg, T. Hatting, K. Heissig, E. P. J. Heizmann, D. M. Hills, J. Hooker, R. Kraft, W. Krzemiński, E. Ladier, B. Lange-Badré, M. Philippe, G. Plodowski, A. Prieur, J.-P. Saint Martin, M. Septfontaine, G. Storch, C. Sudre, J. Sudre, R. H. Tedford, D. Vidalenc, and F. Wiedenmayer. This research was supported by the Alexander von Humboldt Foundation.

\section{References}

Agassiz L. 1846. Nomenclatoris zoologici. Index universalis, continens nomina systematica classium, ordinum, familiarum et generum animalium omnium, tam viventium quam fossilium, secundum ordinem alphabeticum unicum disposita, adjectis homonymiis plantarum, nec non variis adnotationibus et emendationibus. Jent et Gassmann, Solothurn: I - VIII + 1-393.

Anonymous 1839. Marte fossile. L'Écho du Monde Savant 5: $42-43$.

Barnes L. G. 1989. A new enaliarctine pinniped from the Astoria Formation, Oregon, and a classification of the Otariadae (Mammalia: Carnivora). Contr. Sci. nat. Hist. Mus. Los Angeles County 403: $1-26$.

Baskin J. A. 1982. Tertiary Procyoninae (Mammalia: Carnivora) of North America. J. Vertebr. Paleont. 2: $71-93$.

Baskin J. A. 1989. Comments on New World Tertiary Procyonidae (Mammalia: Carnivora). J. Vertebr. Paleont. 9: 110 - 117.

Beaumont G. de 1964. Essai sur la position taxonomique des genres Alopecocyon Viret et Simocyon Wagner (Carnivora). Eclog. geol. Helv. 57: 829 - 836.

Beaumont G. de 1965. Contribution à l'étude du genre Cephalogale Jourdan (Carnivora). Schweiz. paläont. Abh, 82: $1-34$.

Beaumont $G$ de 1968. Note sur la région auditive de quelques Carnivores. Arch. Sci,, Genève 21: $213-223$.

Bonis L. de 1973. Contribution à l'étude des Mammifêres de l'Aquitanien de l'Agenais. Rongeurs Carnivores - Périssodactyles. Mém. Mus. natn. Hist. nat., Paris, N. Sér. (C) 28: 1- 192.

Bonis L. de 1976. Découverte d'un crîne d'Amphictis (Mammalia, Carnivora) dans l'Oligocène supérieur des Phosphorites du Quercy (Lot), C. R. Séanc. Acad. Sci., Paris (D) 283: 327 - 330.

Bowdich T. E. 1821. An analysis of the natural classifications of Mammalia, for the use of students and travellers. J. Smith, Paris: 1 - 115.

Broom R. 1908. On some new Therocephalian reptiles. Ann. S. Afr. Mus. 4: $361-367$.

Bryant H. N. 1989. An evaluation of cladistic and character analyses as hypothetico-deductive procedures, and the consequences for character weighting. Syst. Zool. 38: $214-227$.

Bryant H. N. 1991. The polarization of character transformations in phylogenetic systematics: role of axiomatic and auxiliary assumptions. Syst. Zøol. $40: 433-445$.

Cirot E. 1988. Caractères et classification des Fissipèdes: exemple du genre Amphicynodon (Oligocène inférieur des Phosphorites du Quercy). Mém. DEA, Lab. Paléont. Vertébr. Paléont. hum. Univ. P. et M. Curie, Paris: $1-46$. 
Cirot E. 1992. Étude phylogénétique de quelques genres d'Arctoidea de l'Oligocène eurasiatique. Comparaison des données morphologiques et moléculaires. Vols 1, 2. Ph. D. Diss., Fac. Sci. fondament. appl. Univ. Poitiers, Poitiers: $1-152$.

Cirot $\mathrm{B}$ and de Bonis L. 1992. Révision du genre Amphicynodon, Carnivore de l'Oligocène. Palaeontographica (A) 220: $103-130$.

Clark J., Beerbower J. R., and Kietzke K. K. 1967. Oligocene sedimentation, stratigraphy, paleoecology and paleoclimatology in the Big Badlands of South Dakota. Fieldiana, Geol. Mem. 5 : I - VIII + $5-158$.

Clark J. and Guensburg T. E. 1972. Arctoid genetic characters as related to the genus Parictis. Fieldiana, Geol. 26: 1 - 76 .

Crusafont Pairó M. 1971. Estado actual de los estudios paleomastológicos en España. Mem. r. Acad. Cienc. Artes Barcelona, Tercera Época 41: 139 - 159.

Crusafont Pairó M. 1973. Mammalia tertiaria Hispaniae. [In: Fossilium catalogus, 1 (121). F. Westphal, ed.]. W. Junk b. v., the Hague: I - IV + $1-198$.

Crusafont Pairó M. and Kurtén B. 1976. Bears and bear-dogs from the Vallesian of the Vallés-Penedés basin, Spain. Acta zool. fenn. 144: 1 - 29.

Dawkins W. B. 1888. On Ailurus anglicus, a new carnivore from the Red Crag. Q. J. geol. Soc. Lond. 44: $228-230$

Decker D. M. and Wozencraft W. C. 1991. Phylogenetic analysis of Recent procyonid genera. J. Mamm. 72: 42 - 55 .

Dehm R. 1950. Die Raubtiere aus dem Mittel-Miocän (Burdigalium) von Wintershof-West bei Eichstätt in Bayern. Abh. bayer. Akad. Wiss, Math.-naturw. Kl., N. F. 58: 1 - 141.

Desmarest A. G. 1826. Potamophile, Potamophilus, (Crust.). [In: Dictionnaire des sciences naturelles, dans lequel on traite méthodiquement des différens êtres de la nature, considérés soit en eux-mêmes, d'après l'état actuel de nos connoissances, soit relativement à l'utilité qu'en peuvent retirer la médecine, l'agriculture, le commerce et les arts]. F. G. Levrault, Strasbourg: 97.

Eldredge N. and Cracraft J, 1980. Phylogenetic patterns and the evolutionary process. Method and theory in comparative biology. Columbia Univ. Press, New York: $\mathbf{- x}+1-349$.

Farris J. S. 1982. Outgroups and parsimony. Syst. Zool. 31: $328-334$.

Farris J. S. 1983. The logical basis of phylogenetic analysis. (In: Advances in cladistics, volume 2. Proceedings of the second meeting of the Willi Hennig Society. N. I. Platnick and V. A. Funk, eds). Columbia Univ. Press, New York: $7-36$.

Filhol H. 1883. Notes sur quelques mammifères fossiles de l'époque miocène. Arch. Mus. Hist. nat. Lyon 3: $1-97$.

Fischer [von Waldheim] G. 1817. Adversaria zoologica. Mém. Soc. imp. Nat. Moscou 5: 357 - 472.

Flower W. H. 1869. On the value of the characters of the base of the cranium in the classification of the order Carnivora, and on the systematic position of Bassaris and other disputed forms. Proc. scient. Meet. zool. Soc, Lond. 1869:4-37.

Flynn J. J., Neff N. A., and Tedford R. H. 1988. Phylogeny of the Carnivora. IIn: The phylogeny and classification of the tetrapods, 2. M. J. Benton, ed.J. Syst. Ass. spec. Vol. 35B. Clarendon Press, Oxford: $73-115$.

Gaudry A. 1860. Résultats des fouilles entreprises en Grèce sous les auspices de I'Académie. (Suite.). C. R. hebd. Séanc. Acad. Sci, Paris 51: $926-929$.

Geoffroy Saint-Hilaire [É.] 1833. Palaeontographie. Considérations sur des ossemens fossiles la plupart inconnus, trouvés et observés dans les bassins de l'Auvergne. Rev. encycl. 59: 76-95.

Greoffroy Saint-Hilaire [É.] and Cuvier F, 1825. Panda. [In: Histoire naturelle des Mammieres, avec des figures originales, coloriées, dessinées d'après des animaux vivans, 3 (50). [E.] Geoffroy Saint-Hilaire and F. Cuvierl. A. Belin, Paris: $1-3$.

Germar E. F. 1811. Eine neue Käfergattung Potamophilus. N. Schr. naturf. Ges. Halle 1 (6): $39-46$.

Gervais P. 1852. Zoologie et paléontologie françaises (animaux vertébrés) ou nouvelles recherches sur les animaux vivants et fossiles de la France, 2. Arthus Bertrand, Paris $1848-1852: 1-16+1-$ $8+1-8+1-8+1-12+1-8+1-14+1-16$. 
Ginsburg L. 1961. La faune des Carnivores miocènes de Sansan (Gers). Mém. Mus, natn. Hist. nat., Paris, N. Sér. (C) 9: $1-190$.

Ginsburg L. 1966. Les Amphicyons des Phosphorites du Quercy. Ann. Paléont, Vertébr. 52: 21 - 64.

Ginsburg I. 1982. Sur la position systématique du petit Panda, Ailurus fulgens (Carnivora, Mammalia). Géobios, Mém. spéc. 6: 247 - 258.

Gloger C. W. L. 1841: Gemeinnütziges Hand- und Hilfsbuch der Naturgeschichte. Für gebildete Leser aller Stände, besonders für die reifere Jugend und ihre Lehrer, 1. Verl. v. A. Schulz \& Comp., Wroclaw 1841 - 1842: I - XXXXIV + $1-495$.

Gray J. E. 1825. An outline of an attempt at the disposition of Mammalia into tribes and families with a list of the genera apparently appertaining to each tribe. Ann. Philos., N. Ser. 10: $337-344$.

Hennig W. 1966. Phylogenetic systematics. Univ. Illinois Press, Urbana: $1-263$.

Heráň I. 1974. Poznámky k výskytu sagitálního hrỏebene (crista sagittalis externa) u kunovitých Selem. Lynx, Ser. n. 16: $101-111$.

Hough J. R. 1948. The auditory region in some members of the Procyonidae, Canidae, and Ursidae. Its significance in the phylogeny of the Carnivorc. Bull. am. Mus. nat. Hist. 92: $67-118$.

Hunt R. M., Jr 1974. The auditory bulla in Carnivora: an anatomical basis for reappraisal of carnivore evolution. J. Morph. 143: $21-75$.

Hunt R. M., Jr 1977. Basicranial anatomy of Cynelos Jourdan (Mammalia: Carnivora), an Aquitanian amphicyonid from the Allier Basin, France. J. Paleont. 51: $826-843$.

Hunt R. M., Jr 1987. Evolution of the aeluroid Carnivora: significance of auditory structure in the nimravid cat Dinictis. Am. Mus. Novit. 2886: $1-74$.

Hunt R. M., Jr 1991. Evolution of the aeluroid Carnivora: viverrid affinities of the Miocene carnivoran Herpestides. Am. Mus, Novit. 3023: $1-34$.

Illiger C. 1811. Prodromus systematis mammalium et avium additis terminis zoographicis utriusque classis. C. Salfeld, Berlin: I - XVIII + $1-302$.

Jourdan [C.] 1861. Des terrains sidérolitiques. C. R. hebd. Séanc. Acad, Sci,, Paris 53: 1009 - 1014.

Jourdan [C.] 1862. Des terrains sidérolitiques. Rev. Soc. sav., Sci. math. phys. nat. 1; $130-133$.

Kaup J. 1832. Vier neue Arten urweltlicher Raubthiere, welche im zoologischen Museum zu Darmstadt aufbewahrt werden. Arch. Miner. Geogn. Bergb. Hüttenk. 5: 150-158.

Kaup J. 1861. Beitraege zur naeheren Kenntniss der urweltlichen Saeugethiere, 5. Eduard Zernin, Darmstadt: $1-32$.

Klug F. 1842. Uber die Insectenfamilie Heterogyna Lat. und die Gattung Thynnus F. insbesondere. Abh. k. Akad. Wiss. Berlin, Phys.-math. Kl, 1840: $1-44$.

Kretzoi M. 1945. Bemerkungen über das Raubtiersystem. Ann. hist.-nat. Mus. natn. hung. 38: $59-83$.

Kretzoi M. 1947. New names for mammals. Ann. hist.-nat. Mus. natn. hung. 40: $285-287$.

Kurtén B. and Anderson E. 1980. Pleistocene mammals of North America, Columbia Univ. Press, New York, i - xviii + $1-443$.

Lange B. 1969. Un nouveau Musteliné des Phosphorites du Quercy, Mustelictis pivetealii. C. R. Séanc. Acad. Sci., Paris (D) 268: 2870 -2872.

Lange B. 1970. Mustelictis piveteaut, mustélidé nouveau des Phosphorites du Quercy. Ann. Paléont., Vertébr. 56: $73-91$.

Lartet E. 1851. Notice sur la colline de Sansan, suivie d'une récapitulation des diverses espèces d'animaux vertébrés fossiles, trouvés soit à Sansan, soit dans d'autres gisements du terrain tertiaire miocène dans le bassin sous-pyrénéen. J.-A. Portes, Auch: $1-42$.

Lavocat R. 1952. Sur les affinités de quelques carnassiers de l'oligocene d'Europe, notamment du genre Plesictis Pomel et du genre Proailurus Filhol. Mammalia 16: 62 - 72.

Lindsay E. H. and Tedford R. H. 1990. Development and application of land ruammal ages in North America and Europe, a comparison. [In: European Neogene mammal chronology. E. H. Lindsay, V. Fahlbusch, and P. Mein, eds]. NATO ASI Ser. (A) 180. Plenum Press, New York: $601-624$. 
Lydekker R. 1885. Catalogue of the Fossil Mammalia in the British Museum, (Natural History) Cromwell Road, S. W. Part I. Containing the Orders Primates, Chiroptera, Insectivora, Carnivora, and Rodentia. Order Trustees, London: $\mathrm{i}-\mathrm{xxx}+1-268$.

Maddison W. P., Donoghue M. J., and Maddison D. K. 1984. Outgroup analysis and parsimony. Syst. Zool. 33: $83-103$.

Matthew W. D. 1918. Contributions to the Snake Creek fauna. With notes upon the Pleistocene of western Nebraska. American Museum Expedition of 1916. Bull. am. Mus. nat. Hist. 38: 183-229.

Matthew W. D. and Granger W. 1924. New Carnivora from the Tertiary of Mongolia. Am. Mus. Novit. 104: $1-9$.

Mein P. 1990. Updating of MN zones. (In: European Neogene mammal chronology. E. H. Lindsay, V. Fahlbusch, and P. Mein, eds]. NATO ASI Ser. (A) 180. Plenum Press, New York: $73-90$.

Meyer H. von 1847. Frankfurt a. M., 4. Januar 1847. l...l. N. Jb. Miner. Geogn. Geol. Petrefakten-K. 1847: $181-196$

Mitchell E. and Tedford R. H. 1973. The Enaliarctinae, a new group of extinct aquatic Carnivora and a consideration of the origin of the Otariidae. Bull. am. Mus. nat. Hist. 151: $201-284$.

Mödden C. 1991. Bavarictis gaimersheimensis n. gen. n. sp., ein fruher Mustelide aus der oberoligozänen Spaltenfüllung Gaimersheim bei Ingolstadt. Mitt. bayer. Staatssamml. Paläont. hist. Geol. 31: 125 - 147.

Muizon C. de 1982. Les relations phylogénétiques des Lutrinae (Mustelidae, Mammalia), Géobios, Mém. spéc. 6: $259-277$.

Muller S. 1838. Over eenige nieuwe zoogdieren van Borneo. Tijdschr. natuurl. Geschied. Physiol, 5 $(1838-1839)$ : $134-150$.

Petter G. 1967. Paragale hürzeleri nov. gen., nov. sp., Mustélidé nouveau de l'Aquitanien de l'Allier. Bull. Soc. géol. Fr. (7) 9: $19-23$.

Pohle H. 1917. Pseudobassaris riggsi, gen. n., spec. nov. für Amphictis spec. Riggs. Sber. Ges. naturf. Freunde Berl. 1917: $403-411$.

Pohle H. 1920. Zur Kenntris der Raubtiere. II. Die Stellung der Gattungen Amphictis und Nandinia. Sber. Ges. naturf. Freunde Berl, 1920: $48-62$.

Pomel A. 1846a. Quelques nouvelles considérations sur la paléontologie de l'Auvergne. Bull. Soc. géol. Fr. (2) $3(1845-1846): 198-231$.

Pomel A. 1846 b. Mémoire pour servir à la géologie paléontologique des terrains tertiaires du département de l'Allier. Bull. Soc. géol. Fr. (2) 3 (1845 - 1846): $353-373$.

Pomel A. 1847. Note sur des animaux fossiles découverts dans le département de l'Allier. Bull. Soc. géol. Fr. (2) 4 (1846 - 1847): 378 - 385 .

[Pomel A.] 1853. Catalogue des vertébrés fossiles (suite.). Ann. scient. litt. ind. Auvergne 26: 81 - 229.

Qiu Z. and Schmidt-Kittler N. 1982. On the phylogeny and zoogeography of the leptarctines (Carnivora, Mammalia). Paläont. Z. 56: 131 - 145.

Queiroz K. de 1985. The ontogenetic method for determining character polarity and its relevance to phylogenetic systematics. Syst. Zool. 34: $280-299$.

Queiroz K. de and Gauthier J. 1990. Phylogeny as a central principle in taxonomy: phylogenetic definitions of taxon names. Syst. Zool. 39: $307-322$.

Radinsky L. 1977. Brains of early carnivores. Paleobiology 3: $333-349$.

Roberts M. S. and Gittleman J. L. 1984. Ailurus fulgens. Mamm. Spec. 222: I - 8.

Roth C. 1987. Die Raubtierfauna der miozänen Spaltenfullungen Petersbuch 2 und Erkertshofen 2. Taxonomie - Stratigraphie - Okologie. Ph. D. Diss., Inst. Geowiss. Univ. Mainz, Mainz: $1-252$.

Savage R. J. G. 1957. The anatomy of Potamotherium, an Oligocene lutrine. Proc. zool. Soc. Lond. 129 : $151-244$.

Schlosser M. 1899. Parailurus anglicus und Ursus Böckhi aus den Ligniten von Baróth-Köpecz, Comitat Hăromszék in Ungarn. Mitt. Jb. k. ung. geol. Anst. 13: 67-95.

Schmidt-Kittler N. 1981. Zur Stammesgeschichte der marderverwandten Raubtiergruppen (Musteloidea, Carnivora). Eclog. geol. Helv, 74: 753-801. 
Schmidt-Kittler N. 1984. On the phylogenetic and biogeographic history of the musteloid carnivores in east and southeast Asia. [In: The evolution of the east Asian environment, 2. R. O. Whyte, T.N. Chiu, C.-K. Leung, and C.-L. So, eds]. Cent. azian Stud. occ. Pap. Monogr. 59. Univ. Hong Kong, Hong Kong: $710-723$.

Schmidt-Kittler N., Godinot M., Franzen J. L., Hooker J. J., Legendre S., Brunet M., and Vianey-Liaud M. 1987. European reference levels and correlation tables. [In: International Symposium on Mammalian Biostratigraphy and Paleoecology of the European Paleogene - Mainz, February 18th - 21st 1987. N. Schmidt-Kittler, ed]. Münchn. geowiss. Abh. (A) 10: $13-31$.

Segall W. 1943. The auditory region of the arctoid carnivores. Zool. Ser. Field Mus. nat. Hist. 29: $33-59$.

Simpson G. G. 1945. The principles of classification and a classification of mammals. Bull. am. Mus. nat. Hist. 85: $1-X V I+1-350$.

Simpson G. G. 1946. Palaeogale and allied early mustelids. Am. Mus. Novit. 1320: 1 - 14.

Springhorn R. 1976. Zur Craniologie südfranzósischer oligozäner Amphicyonidae (Carnivora, Mam. malia). Palaeontographica (A) 152: 1 - 13.

Springhorn R. 1977. Revision der alttertiären europäischen Amphicyonidae (Carnivora, Mammalia). Palaeontographica (A) 158: 26 - 113 .

Stirton R. A. 1960. A marine carnivore from the Clallam Miocene formation, Washington. Its correlation with nonmarine faunas. Univ. Calif. Publ. geol. Sci. 36: $345-368$.

Tedford R. H. 1976. Relationship of pinnipeds to other carnivores (Mammalia). Syst. Zool. 25 $363-374$.

Tedford R. H., Barnes L. G., and Ray C. E. 1991. Earliest Miocene littoral arctoid, Kolponomos. J. Vertebr. Paleont. 11 (3, suppl.): 57A.

Tedford R. H. and Gustafson E. P. 1977. First North American record of the extinct panda Parailurus. Nature 265: $621-623$.

Thenius E. 1949. Die Carnivoren von Göriach (Steiermark). Beiträge zur Kenntnis der Säugetierreste des steirischen Tertiärs IV. Sber. öst. Akad. Wiss., Math.-naturw. Kl. (I) 158: $695-762$.

Thenius E. 1977. Zur systematischen Stellung von Protursus (Carnivora, Mammalia). Anz. math.-naturw. Kl. öst. Akad. Wiss. 1977 (3): $37-41$.

Thorpe M. R. 1921. Two new fossil Carnivora. Am. J. Sci. (5) 1: $477-483$.

Thorpe M. R. 1922. A new generic name for Pliocyon Marshi. Am. J. Sci. (5) 3: 97.

Viret J. 1933. Contribution à l'étude des carnassiers miocènes de la Grive-Saint-Alban (Isère). Trav. Lab. Géol. Fac. Sci. Lyon 21 (18): 1 - 37.

Viret J. 1951. Catalogue critique de la faune des Mammiferes miocènes de la Grive Saint-Alban (Isère). Première partie: Chiroptères, Carnivores, Édentés Pholidotes. N. Arch. Mus. Hist. nat. Lyon 3: 1 - 104.

Wagner A. 1854. Bericht über die urweltlichen Arten von Wirbelthieren, deren Knochen-Ueberreste durch die von dem Herrn Akademiker Dr. Johannes Roth bei Pikermi in Griechenland während des Winters 1852/53 unternommenen Ausgrabungen aufgefunden wurden. Gelehrte Anzeigen (Bull. k. bayer. Akad. Wiss. 10) 38: $337-343$.

Wagner A. 1857. Neue Beiträge zur Kenntniss der fossilen Säugethier-Ueberreste von Pikermi. Abh. k. bayer. Akad. Wiss. (II) 8: $109-158$.

Wagner A. 1858. Geschichte der Urwelt, mit besonderer Berücksichtigung der Menschenrassen und des mosaisehen Schöpfungsberichtes, 2. 2nd ed. Verl. Leopold Voss, Leipzig: I - VI + $1-528$.

Wagner H. 1976. A new species of Pliotaxidea (Mustelidae: Carnivora) from California. J. Paleont. 50 : $107-127$.

Wang X. and Tedford R. H. 1992. The status of genus Nothocyon Matthew, 1899 (Carnivora): an arctoid not a canid. J. Vertebr. Paleont. 12: $223-229$.

Watrous L. E. and Wheeler Q. D. 1981. The out-group comparison method of character analysis. Syst. Zool. 30: 1 - 11 . 
Wegner R. N. 1913. Tertiaer und umgelagerte Kreide bei Oppeln (Oberschlesien). Palaeontographica 60: $175-274$

Wiig $\emptyset .1983$. On the relationship of pinnipeds to other carnivores. Zool. Scr. 12: $225-227$.

Winge H. 1895. Jordfundne og nulevende Rovdyr (Carnivora) fra Lagoa Santa, Minas Geraes, Brasilien. Med Udsigt over Ruvdyrenes indbyrdes Slaegtskab. IIn: E Museo Lundii. En Samling af Afhandlinger om de i det indre Brasiliens Kalkstenshuler af Professor Dr. Peter Vilhelma Lund udgravede og i den Lundske palaeontologiske Afdeling af Kjøbenhavns Universitets zoologiske Museum opbevarede Dyre- og Menneskeknogler, 2 (2, IV). C. F. Lütken, ed]. H. Hagerups Boghandel, Copenhagen: $1-130$

Wortman J. L. 1901. Studies of Eocene Mammalia in the Marsh collection, Peabody Museum. Am. J. Sci. (4) 12: $143-154$.

Wozencraft W. C. 1989. The phylogeny of the Recent Carnitora. (In: Carnivore behavior, ecology, and evolution. J. L. Gittleman, ed]. Cornell Univ. Press, Ithaca: 495 - 535.

Wyss A. R. 1987. The walrus auditory region and the monophyly of pinnipeds. Am. Mus. Novit. 2871: $1-31$.

Wyss A. R. and Flynn J. J. 1993. A phylogenetic analysis and definition of the Carnivora. IIn: Mammal phylogeny: Placentals. F. S. Szalay, M. J. Novacek, and M. C. McKenna, eds]. Springer-Verl., New York: $32-52$.

Zdansky O. 1924. Jungtertiäre Carnivoren Chinas. Palaeont. sin. (C) 2 (1): 1 - 155.

Received 8 Notember 1993, accepted 25 November 1993. 